Canadian Science Publishing

Canadian Journal of Earth Sciences Revue canadienne des sciences de la Terre

\title{
Paleoenvironment of the Quilchena flora, British Columbia, during the Early Eocene Climatic Optimum
}

\begin{tabular}{|r|l|}
\hline Journal: & Canadian Journal of Earth Sciences \\
\hline Manuscript ID & cjes-2015-0163.R1 \\
\hline Manuscript Type: & Article \\
\hline Complete List of Authors: & $\begin{array}{l}\text { Mathewes, Rolf W.; Simon Fraser University, } \\
\text { Greenwood, David R.; Environmental Science } \\
\text { Archibald, S. Bruce; Simon Fraser University, Canada, Department of } \\
\text { Biological Sciences }\end{array}$ \\
\hline Keyword: & \\
\hline & \\
\hline
\end{tabular}




\section{Climatic Optimum}

11

12

13 Mathewes ${ }^{1}$, Rolf W. Department of Biological Sciences, Simon Fraser University, Burnaby, 14 BC, Canada, V5A 1S6.

15 Greenwood, David R., Department of Biology, Brandon University, Brandon, MB, Canada, 16 R7A 6A9.

17 Archibald, S. Bruce, Department of Biological Sciences, Simon Fraser University, Burnaby, 18 BC, Canada, V5A 1S6. Museum of Comparative Zoology, Cambridge, MA, USA; Royal 19 BC Museum, Victoria, BC, Canada V8W 1A1.

20

21

22

231 corresponding author (mathewes@sfu.ca)

24 


\section{ABSTRACT}

The Quilchena fossil locality is dated $(51.5 \pm 0.4 \mathrm{Ma})$ to the Early Eocene Climatic Optimum (EECO), and is reconstructed as the warmest and wettest of the Early Eocene upland sites from the Okanagan Highlands of British Columbia and northern Washington State. Mean annual temperature (MAT) is estimated from leaf margin analysis, using 55 dicot morphotypes, as $16.2^{\circ} \mathrm{C} \pm 2.1^{\circ} \mathrm{C} / 14.6 \pm 4.8^{\circ} \mathrm{C}$. Using bioclimatic analysis of 45 nearest living relatives, a moist mesothermal climate is indicated (MAT $12.7-16.6^{\circ} \mathrm{C}$; cold month mean temperature (CMMT) $3.5-7.9^{\circ} \mathrm{C}$; mean annual precipitation (MAP) 103-157 $\mathrm{cm} / \mathrm{yr}$. Leaf size analysis estimates MAP at $121 \pm 39 \mathrm{~cm} \cdot \mathrm{a}^{-1}$. Estimates from the climate leaf analysis multivariate program (CLAMP) corroborate these results, although with a slightly cooler MAT $\left(13.3^{\circ} \mathrm{C} \pm 2.1^{\circ} \mathrm{C}\right)$. Plants that support an interpretation of warm winters with minimal or no frost include Azolla, Glyptostrobus, Taxodium, Keteleeria, Pseudolarix, Eucommia, Dipteronia, Hovenia, and Ternstroemia and others. These thermophilous elements occur together with temperate genera such as Alnus, Betula, Ulmus, Calocedrus, and Fraxinus. Palynological assemblages at Quilchena are dominated by bisaccate conifers and Cupressaceae. Common angiosperms include Ulmus type, triporates, Pterocarya and Alnus. Insect fossils at Quilchena that today inhabit tropical and subtropical regions also support warm and equable climate without significant frost, and include obligate palmfeeding beetles (Pachymerina), which indicate CMMT perhaps as high as $8^{\circ} \mathrm{C}$. These are found together with temperate aphids, wasps, giant lacewings, brown lacewings and a panorpoid scorpionfly, supporting an interpretation of equable climatic conditions during the EECO. 


\section{INTRODUCTION}

The Okanagan Highlands series of fossil sites are interpreted as an Eocene interior upland region of central British Columbia to northern Washington State spanning ca. 1000 km north to south (Fig. 1) and comprises a variety of upland depositional basins (Wilson 1977; Greenwood et al. 2005; Archibald et al. 2011; Smith et al. 2012). The Early Eocene fossiliferous sediments from $\mathrm{OH}$ paleolakes and swamps contain fossil assemblages that are recognized as Lagerstätten, with extremely well-preserved plant and insect macrofossils (Archibald et al. 2011) along with a diverse pollen and spore flora. These fossil biotas provide evidence of mixed thermophilic and temperate associations of plants and insects (Archibald and Mathewes 2000; Greenwood et al. 2005; Smith et al. 2012; Archibald et al. 2010; Archibald et al. 2014) with occurrences of 'subtropical' or mesothermal (Mean annual temperature $\left.(\mathrm{MAT})>13<20^{\circ} \mathrm{C}\right)$ biota mixed with microthermal $\left(\mathrm{MAT} \leq 13^{\circ} \mathrm{C}\right)$ or 'temperate' plants and insects. Earlier palynological analyses noted the abundance of pollen from various bisaccate conifer genera in the Pinaceae such as Pinus and Picea (Hills 1965) in these upland forests, suggesting microthermal conditions. This is contrasted with the identification of rare palm-like pollen (Sabal granopollenites or Liliacidites) and frequency of pollen of other thermophilic taxa such as Pseudolarix in the Pinaceae (Moss et al. 2005) in many Okanagan Highlands sites, leading to interpretations of a temperate but equable and frost-free climate. In contrast, western Eocene floras in the coastal Puget Group of Washington State and Huntington and Chuckanut Formations of the Fraser-Puget Lowlands reflect mesothermal to in part megathermal (MAT $\geq 20^{\circ} \mathrm{C}$ ) climate, including forests with palms and other thermophilic indicator plants based on pollen (Rouse 1962, Hopkins 1969), and plant macrofossils including Glyptostrobus and tree ferns as well as abundant palms (Mustoe and Gannaway 1997). Recent paleoclimatic analysis using leaf physiognomy of an 
expanded database of 125 leaf morphotypes from the Eocene Chuckanut Formation of Washington State (Breedlovestrout et al. 2013) suggests tropical mean annual paleotemperatures reached up to $28.8^{\circ} \mathrm{C}$ for the lower undated Bellingham Bay unit which may include Paleocene sediments. In contrast, the Okanagan Highlands fossil biotas appear to mostly reflect microthermal climates, supporting a species-rich mixed conifer and deciduous broadleaved forest with components of evergreen dicots and some thermophilous conifers such as Keteleeria, Pseudolarix, Glyptostrobus, and Taxodium.

The Quilchena fossil locality appeared to represent the warmest of the Okanagan Highlands localities based on preliminary paleobotanical data (Greenwood et al. 2005), and the current study attempts to confirm this climatic interpretation. The site is dated (Villeneuve and Mathewes 2005) near the termination (51.5 Ma) of the Early Eocene Climatic Optimum (EECO), a sustained period of globally warm climates dated to between 51-53 Ma by Zachos et al. (2008). This paper updates some aspects of the Quilchena paleoflora, with emphasis on climatically significant indicator taxa, and provides new information on paleoclimate parameters for this site using plant macrofossils, pollen and insects that were not available for inclusion in the report of Greenwood et al. (2005). An updated taxonomic analysis of the flora will be published later, when further study of new taxa and new fossil occurrences is complete.

\section{MATERIALS AND METHODS}

\section{Fossil Locality}

The fossil flora was collected from a small exposure of Coldwater Beds on the west side of Quilchena Creek $\left(50^{\circ} 7.667^{\prime} \mathrm{N}, 120^{\circ} 30.354^{\prime} \mathrm{W}\right)$ at $720 \mathrm{~m}$ a.s.l. about $3 \mathrm{~km}$ due south of the settlement of Quilchena (Mathewes and Brooke, 1971) in south-central 
British Columbia, Canada (Fig. 1). The Quilchena coal basin as described in Cockfield (1948) is about $11 \mathrm{~km}$ long from north to south and $3 \mathrm{~km}$ wide. It is a heavily driftcovered area with few exposures of the sandstones, shales, and minor coal seams of the Coldwater Beds, either at Quilchena or at the similar Merritt coal basin. Coldwater rocks are extensively folded, leading to scattered outcrops (Cockfield 1948, map 886A) with variable dips and strikes, suggesting they may be remnants of a former connected basin around Merritt and Quilchena. Fossil plants were reported from sites near Quilchena before 1890 (Dawson 1890; Penhallow 1908); however, the first comprehensive report from the Quilchena locality was published by Penhallow (1908). The fossil collections from the Quilchena Creek exposure reported here represent occasional work over more than 40 years, involving various colleagues as well as students from undergraduate and graduate classes from the Department of Biological Sciences at SFU (Mathewes and Brooke 1971; Guthrie 1995; Archibald and Mathewes 2000). Guthrie (1995) excavated and documented a detailed section through the Quilchena Creek fossil deposit, exposed along a roadcut on the west side of Quilchena Creek. Guthrie recognised two lithofacies groups; a fine-grained shale in lower facies assemblage 1 and a coarser mudstone and shale upper facies assemblage 2 (Figs 2, 3). Facies 1 shales are fissile, light in colour, clay-rich, and highly fragmented, probably due to glacial overriding as well as uplift, and dip between 23 and 32 degrees to the south (Guthrie 1995). Facies 2 mudstones are darker, blocky and less fractured, and exhibit more pronounced dips around 39-48 degrees (Fig. 3).

Radiometric analysis $\left({ }^{40} \mathrm{Ar}-{ }^{39} \mathrm{Ar}\right)$ of sanidine from the base of Quilchena tephra (Fig. 2, unit 31) gave an age of 51.5 $\pm 0.4 \mathrm{Ma}$, supporting an Early Eocene (Ypresian) assignment for the fossil site (Villeneuve and Mathewes, 2005). Eocene 
sedimentary rocks of the nearby Merritt basin have been recently correlated with the Princeton Group, indicating a closer physical relationship for the Quilchena fossil assemblages to fossil sites $<100 \mathrm{~km}$ to the south (Allenby Formation, e.g., One Mile Creek and Thomas Ranch) than to those of the Kamloops Group (e.g., McAbee and Hat Creek), about equidistant to the north (Read 2000). Coal deposits associated with lacustrine shales in the Merritt and Quilchena basins indicate regional swamp as well as lake environments. Coal discovered by Diamond Vale Collieries on the east side of Quilchena Creek valley was mined for local use (Cockfield, 1948) and spoil from the collapsed mine entrance provided sediment for pollen analysis in this study. Stratigraphic correlations between the east and west side sediments are unknown.

The lacustrine origin of the fossiliferous shales is confirmed by aquatic fossils, including scales of bowfin (Amia) and abundant body fossils of juvenile suckers (Amyzon brevipinne) that also are found as bony remains in scattered fish-bone pellets, presumably regurgitated by piscivorous birds (Wilson, 1987). Rare fossil feathers confirm the presence of birds, and a tooth of a small primitive insectivore is the only evidence of mammals. Altough Guthrie (1995) identified another tooth as possibly of a small crocodilian, subsequent study suggests it is likely a fish tooth.

Based on the radiometric date for Quilchena, the flora is coeval with the warmest part of the Early Eocene, the Early Eocene Climatic Optimum, or EECO (Zachos et al. 2008). The Quilchena flora was partially described from old published records, mostly Penhallow (1908), reviewed in Mathewes and Brooke (1971) and updated briefly in Greenwood et al. (2005) and Dillhoff et al. (2005). Many of the older records are of fragmentary leaves that require detailed re-examination and additional reproductive organs before generic identifications are verified. New data based partly on previously 
unrecorded taxa are presented here. We apply leaf physiognomic methods as palaeoclimatic proxies to estimate mean annual temperature and mean annual precipitation (MAP) for Quilchena. These new paleoclimate data are compared to previously published estimates (Greenwood et al., 2005) using both leaf physiognomy, and estimates based on identification of the nearest living relatives (NLR) of the fossil flora.

\section{Paleoenvironmental Analysis}

Paleoclimate is estimated in this work using two quantitative approaches in combination, designed to provide an ensemble of estimates: nearest living relative (NLR) analysis and leaf physiognomy (e.g., Greenwood et al. 2003, 2005; West et al. 2015). Bioclimatic analysis uses the co-existence approach of Mosbrugger and Utescher (1997), and requires the development of 'climatic profiles' (i.e., climatic parameters such as MAT and MAP) using bioclimatic analysis of distributions of modern plant genera. The first step of this approach is to identify as many "nearest living relatives" (NLRs) as possible in the fossil flora (macroflora; Table 2). Only macroflora were used for our analysis since pollen may include regional elements by long distance dispersal. Then a library of climatic profiles is produced for several key taxa based on climatic values such as MAT, MAP, and coldest month mean temperature (CMMT) (Kershaw and Nix, 1988; Greenwood et al., 2003 \& 2005; West et al., 2015). The climatic profiles used here were from three sources: a study of North American tree genera (Thompson et al. 1999, 2000); the compilation of Chinese plant climate profiles by Fang et al. (2011), which includes several genera extinct in North America today but widespread and speciose in China (e.g., Keteleeria); and a compilation of North American taxa climate ranges developed by one of us from resources available through Natural Resources 
Canada (2012) and and the Global Biodiversity Information Facility (www.gbif.org/)

(see Archibald et al., 2014 and Eldrett et al. 2014). The zone of overlap, or 'coexistence interval' for a set of NLRs defines the most likely climate space occupied for the fossil flora (Kershaw and Nix 1988; Mosbrugger and Utescher 1997; Greenwood et al. 2003 \& 2005; Eldrett et al. 2014). The estimate for each climate parameter (e.g. MAT, MAP, and CMMT) from bioclimatic analysis is the mean value of the 10th and 90th percentile of the maximum and minimum values across all taxa recorded in a sample, with the total range between these plotted as an "error bar" (Greenwood et al. 2005; Eldrett et al. 2014; West et al. 2015). This statistical process objectively removes extreme outliers, consistent with recent recommendations (Grimm and Denk 2012; Thompson et al. 2012). Our analysis used 45 NLRs with climate profiles (Table 1), exceeding the minimum of 12 NLRs recommendation of Thompson et al. (2012).

For the leaf physiognomic analysis, the leaf collection was divided into morphotypes based on their leaf architecture (Ellis et al., 2009). Data on leaf size (sensu Wilf et al. 1998) and margin type were scored for each morphotype for use in leaf margin analysis (LMA) and leaf area analysis (LAA). Additional leaf characters were scored using the Climate Leaf Analysis Multivariate Program (CLAMP) character definitions and leaf size templates (Yang et al. 2011; Spicer 2015). Leaf margin analysis has been widely applied to North American Paleogene floras (Wolfe, 1979; Greenwood and Wing 1995; Greenwood et al. 2005; Peppe et al. 2011; West et al. 2015). Data from South and North America and East Asia produce essentially the same statistical relationship between leaf margin proportion and MAT (i.e., the same slope and essentially the same intercept) (Greenwood, 2007). Peppe et al. (2011) compiled a new dataset spanning 92 sites covering a broader range of vegetated environments than 
Wolfe's (1979) original compilation, showing a much greater spread in the data and consequently a greater standard error. Two LMA equations are therefore used for the present study; 1) that derived from Wolfe (1979) by Wing and Greenwood (1993), and 2) the 'global' equation from Peppe et al. (2011). The equations are:

$$
\begin{aligned}
& \text { MAT }_{\text {LMA-78 }}=1.141+\left(30.6 \cdot P_{\text {margin }}\right) \\
& \text { MAT }_{\text {LMA-global }}=4.6+\left(20.4 \cdot P_{\text {margin }}\right)
\end{aligned}
$$

where $P_{\text {margin }}$ is the proportion of dicot species where the leaf margin lacks teeth $\left(0<\mathrm{P}_{\text {margin }}<1\right)$

Applying the method of Wilf (1997), the error of the estimate for LMA (Wolfe, 1978 ) is expressed here as the binomial sampling error

$$
\sigma[\mathrm{LMA}]=c \sqrt{ }\left(P_{\text {margin }}\left(1-P_{\text {margin }}\right) / r\right.
$$

where $c$ is the slope from the LMA regression equation, $P_{\text {margin }}$ as defined in (1), and $r$ is the number of species scored for leaf margin type for the individual flora (Table 1). Equation 1 has previously been applied to the Quilchena macroflora by Greenwood et al. (2005), and to other Okanagan Highlands sites (Smith et al. 2012) and so is used here to allow comparisons with the same methods applied. The LMA estimates provided in this study use additional specimens collected at Quilchena since the earlier analysis, and an amended morphotype analysis that recognised 55 dicot morphotypes with leaf margin data, whereas only 46 morphotypes were used by Greenwood et al. (2005). The leaf margin proportion (LMP) for the Quilchena macroflora remains comparable between the two studies. 

precipitation, and Wilf et al. (1998) provided linear regression models that can be applied to Cenozoic fossil leaf floras as a proxy for estimating mean annual precipitation. Here we apply the 'proportion of large leaves' equation from Wilf et al. (1998), as it is simpler to calculate than those authors' 'direct measurement' method. The equation is:

The error of the estimate is calculated using the binomial sampling error of Wilf (1997), on the basis that like LMA (toothed vs. non-toothed), assignment of a morphotype to either the 'large leaf size' category ( $\%$ mesophyll $+\%$ macrophyll $+\%$ megaphyll) or not is binomial. The equation therefore is:

$$
\sigma[\mathrm{LAA}]=c \sqrt{ }\left(P_{\text {large leaves }}\left(1-P_{\text {large leaves }}\right) / r\right.
$$
multiple climate variables in the modern world (Yang et al. 2011; Spicer 2015). As this paleoclimate proxy has been previously applied to several of the Okanagan Highlands floras (e.g., Smith et al. 2012; Dillhoff et al. 2005, 2013) as well as the Chuckanut Fm. flora (Breedslovetrout et al. 2013), it's applied here for the first time to the Quilchena flora using the same leaf morphotypes as used for the univariate methods LMA and LAA.

\section{Pollen analysis}

Five sediment samples of Quilchena sediment were analyzed for pollen and spores, three from the main west side Quilchena Creek exposure, and two from the coal mine 
locality on the east side of Quilchena Creek. Approximately 25 grams of mixed shale fragments, selecting bits from most sediment types, were combined from west side facies 1 and facies 2, and mixed samples from the whole Quilchena Creek exposure. Mine spoil shales from the east side and a sample of ironstone completed the five samples. One aim of this study is to identify the dominant pollen taxa at Quilchena to compare with published records from other Okanagan Highlands sites, and also scan for rare indicator types that might help to confirm macrofossil identifications, or provide new records that might have paleoclimatic indicator value. A second aim is to document pollen taxa with images, since none have been published for Quilchena, and with the exception of a plate in Dillhoff et al. (2013, plate 5), and some older interior pollen records (Hills, 1965, Rouse 1970), the palynoflora of Okanagan Highlands sites is not well illustrated.

After crushing to powder with mortar and pestle, the sediments were treated with hot $10 \% \mathrm{HCl}$ to remove carbonates, and digested in $48 \%$ cold $\mathrm{HF}$ for two days, retreated with hot $\mathrm{HCl}$, washed several times in distilled water, treated with $10 \% \mathrm{KOH}$ in a hot water bath, dehydrated, acetolyzed, washed and stained with safranin O. Some samples were bleached to clear palynomorphs prior to staining and residues were mounted on slides using either glycerol jelly or silicone oil. Slides were prepared for microscopic analysis under a Nikon Eclipse 80i microscope. Photographs were taken using a Nikon DS-L2 digital camera unit, either under brightfield or Nomarski Differential Interference illumination to highlight diagnostic features. 

reproductive organs that relate to paleoclimatic analysis, specifically leaf physiognomic analysis and bioclimatic analysis using nearest living relatives (NLRs). Some of the 45 macrofossil taxa used for bioclimatic analysis of NLR (Table 1) and the 55 leaf morphotypes used for leaf physiognomic analysis are illustrated in figs. 4-6. The paleoclimatic significance of these and other taxa will be apparent from the following sections, and other comments specific to these images follow. other animal fossils, as well as plants like the floating mosquito fern (Azolla, Fig. 4A), Various gymnosperms are used for paleoclimatic analysis and ecological interpretation, such as Calocedrus. (Figs. C,D). The fossil ovulate cone (Fig. 4B) and seed (Fig. 4D, top) compare well with Calocedrus decurrens (Figs. 4C,D bottom) from the temperate Pacific Northwest. For many years the identification of Sequoia at Quilchena was unconfirmed since foliage can be confused with other genera. Figure $4 \mathrm{E}$ is the first confirmation of this genus, based on an ovulate cone attached to foliage shoots. Swamp Cypress (Taxodium) is rarely confirmed from macrofossils in Okanagan Highlands sites, but pendulous staminate inflorescences (Fig. 4F) of thermophilous Taxodium are not rare at Quilchena, supporting a riparian or swamp environmental interpretation. Figure 4G is a foliage shoot of cf. Amentotaxus showing the distinctive stomatal bands on the underside of each leaf. Cuticle is not preserved, so the identification on stomatal and epidermal patterns cannot be confirmed. Chinese Golden Larch (Pseudolarix) macrofossils include cone scales and seeds. Figure $4 \mathrm{H}$ shows a detached ovulate cone 
scale with two winged seeds still attached, with seeds paired at base and wings extending to the apex. Chinese "water pine" or Glyptostrobus was only of theoretical occurrence at Quilchena, since its foliage is highly variable and can be confused with Taxodium. Figure 4I shows two ovulate cones at left that confirm its presence, accompanied by taxodioid foliage, likely also of this genus. Its presence supports both a wet local environment and warm climate, like Taxodium. The only macrofossil confirmation of the thermophilous Asian endemic Keteleeria in the Okanagan 
dispersed fruit (Fig. 5B) is one of several found on shale and mudstone, and this genus has an extensive fossil record in the Okanagan Highlands and elsewhere (Manchester et al. 2009). The distinctive winged mericarps of the maple relative Dipteronia (Fig. 5C) represent another East Asian thermophile like Eucommia.

Figure 5D is a new fossil record for the Okanagan Highlands, representing a large woody capsule that closely matches fruits of the theaceous genus Ternstroemia, particularly the Central American species T. tepezapote, shown with capsule and leaves for comparison (Fig. 5E). The leaves of T. tepezapote are entire-margined, similar in size, venation, and toothless margin to rare fossils at Quilchena (Fig. 5F). Based on this large woody capsule with persistent hypogenous calyx and leaf records, the presence of subtropical Ternstroemia is indicated. A second theaceous genus is represented at Quilchena by numerous leaves in facies 2 (Fig. 5H). These closely resemble modern Gordonia lasianthus of the warm southeastern USA with glandular teeth, brochiodromous secondary venation, and evergreen habit (Fig. 5G). Reproductive material has not been identified at Quilchena, so the assignment of fossils to cf. Gordonia awaits further confirmation from seeds or capsules.

Another new record for the Okanagan Highlands is the identification of the genus Pieris in the family Ericaceae (Figs. 5I-L). One fossil leaf compares well in size, shape, strong midrib, crenate margin, and evergreen appearance with modern Pieris japonica (Fig. 5I). A fossil infructescence (Fig. 5J) and detail of a 5-carpellate capsule (Fig. 5L) matches living Pieris (Fig. 5K) well. The genus is composed of seven living species of shrubs, distributed in montane regions of East Asia, eastern North America and Cuba. Also new to the Okanagan Highlands fossil flora are distinctive leaves of Chinese raisin tree Hovenia (Fig. 5M). The basal leaf structure, with strong secondary 
veins delimiting the lamina is distinctive. Quilchena represents the oldest record of Hovenia known in North America, where it was described from the Lower Oligocene of Oregon, USA (Manchester et al. 2009). The assignment of two leaves (Fig. 5N) to cf. Disanthus is phytogeographically also significant if confirmed. To date, it has been identified by seeds in the Oligocene of Europe, but not recorded in Asia or North America. The one extant species is confined to China and Japan (Manchester et al. 2009). No seeds have been found, but the leaf shape and venation suggest this genus may have been present in the Okanagan Highlands. Figure $5 \mathrm{O}$ is one of two peltate leaves with morphology and venation that is typical of Menispermaceae, although the distinctive fruit stones have not been confirmed. The arrow points to the strong marginal venation (fimbrial vein) that is seen in many menisperms, and in Cissampelos, a close modern pantropical genus.

Figure 6 shows some entire-margined dicot leaf morphotypes used in physiognomic analysis. Plafkeria is an extinct malvaceous taxon (Fig. 66A) with asymmetrical leaf base. Sassafras (Lauraceae) is rarely seen at Quilchena, and the dark carbon film of an unlobed leaf (Fig. 5B) suggests a possible evergreen habit like $S$. hesperia, a common fossil at Republic (Wolfe and Wehr, 1987). A trilobed leaf likely also from the Lauraceae (Fig. 6C) and three other unknown morphotypes (Figs. 6D, E, F) will require further study for identification. A large bignoniaceous leaf (fig. 6G), a cf. Magnoliaceae leaf (Fig. 6H), and an asymmetrical small entire leaf possibly related to Sapindus or Pistacia also require further investigation.

\section{Bioclimatic analysis.}


Forty-five macrofossil taxa were used for the bioclimatic analysis, based on

352 the affinities of these leaf or fruit taxa to living genera (Table 1 and Fig. 7)). In the original analysis provided by Greenwood et al. (2005), cold month mean temperature (CMMT) and mean annual precipitation (MAP) modern climate data was unavailable for taxa only represented in the on-line version of PALAEOFLORA (Mosbrugger \& Utescher, 1997), and so only 25 climate profiles were used to derive those climate variables. In the present study full modern climate range data is available for 45 NLRs, and alternative NLR climate data is used to that of PALAEOFLORA (e.g., Thompson et al. 1999, 2000 \& 2012; Fang et al. 2011; data from Eldrett et al. 2014). Bioclimatic estimates for the Quilchena macroflora were based on the calculated zone of overlap using the 10th and 90th percentiles to give maximum occurrence of all taxa. So for example the mean annual temperature (MAT) zone of overlap cannot include all taxa (Fig. 7A). For MAP (Fig. 7C) the lower limit is considered to perhaps be better defined by the highest $25 \%$ value as rainfall is usually limiting as a lower limit. mesothermal; that is mean annual temperature was $14.6 \pm 2.0^{\circ} \mathrm{C}$ (where mesothermal is MAT $13-20^{\circ} \mathrm{C}$, sensu Wolfe, 1979), and mean annual precipitation (MAP) was estimated in the range $103-156 \mathrm{~cm} / \mathrm{yr}(128 \pm 28.3 \mathrm{~cm} / \mathrm{yr})$. However, based on the distribution of climate profiles for MAP between the majority of NLRs, MAP is considered likely to have been greater than $110 \mathrm{~cm} / \mathrm{yr}$, that is, the $25^{\text {th }}$ percentile for the wettest taxon (Castanea). Winters are reconstructed as being essentially frost free as mean winter temperatures (as cold month mean temperature or CMMT) were estimated in the range $3.5-7.9^{\circ} \mathrm{C}$. Based on the same methodology, the paleoclimate for several 
$12^{\circ} \mathrm{C}$ ) and moist (MAP 90-100 cm/yr)(Greenwood et al. 2005; Smith et al. 2012;

Dillhoff et al. 2013), which suggests that the Quilchena flora, in addition to being among the oldest, is also the warmest and likely wettest. The presence of palm beetles at Quilchena implies the presence of their host palms, consistent with $\mathrm{CMMT}>5^{\circ} \mathrm{C}$, and possibly $8^{\circ} \mathrm{C}$ or higher (Archibald et al. 2014).

\section{Leaf physiognomic analysis.}

The estimates based on leaf physiognomy are presented in Table 2. A total of 55 dicot leaf morphotypes were used for the analysis, which is greater than used for the earlier study (Greenwood et al. 2005). There were 49.1\% of the leaf morphotypes with non-toothed margins $(\mathrm{LMP}=0.491)$. A total of $19.7 \%$ of the leaf morphotypes were assigned to either mesophyll, macrophyll or megaphyll categories. Applying the 'global' LMA equation (eqn. 2) a cooler MAT was estimated, at $14.6 \pm 4.8^{\circ} \mathrm{C}$, vs. 16.2 $\pm 2.1^{\circ} \mathrm{C}$ based on the original LMA equation (eqn. 1). Applying CLAMP, winters were reconstructed as mild and likely frost-free $\left(\mathrm{CMMT} 4.1{ }^{\circ} \mathrm{C} \pm 3.4^{\circ} \mathrm{C}\right)$, corroborating the NLR-based bioclimatic analysis, although with a slightly cooler MAT $\left(13.3^{\circ} \mathrm{C} \pm 2.1^{\circ} \mathrm{C}\right)$ than estimated using BA or LMA, but falling within the errors of all of the estimates. Allowing for the errors of all of the methods, these estimates of MAT overlap, so are not statistically different. Using either LMA estimate, Quilchena in the Early Eocene is shown to have had a lower mesothermal climate. The precipitation estimate of $121 \pm 39$ $\mathrm{cm} \cdot \mathrm{a}^{-1}$, including the errors of the estimates, is comparable to the previous estimate based on bioclimatic analysis, of $128 \pm 28 \mathrm{~cm} \cdot \mathrm{a}^{-1}$ (Table 2). Growing Season Precipitation (GSP) was estimated using CLAMP as $117 \mathrm{~cm} \pm 32 \mathrm{~cm}$, with the growing season estimated to be 7.6 months in length. Mean annual precipitation and GSP are not 
comparable, but the GSP estimate is consistent with the higher MAP estimate provided by our NLR-based bioclimatic analysis (Table 2).

In order to establish a likely analog climate and environment in the modern world, the climates for a number of equable sites in North America, the meso-American tropical highlands and sites in Australia were compared with the estimates from bioclimatic analysis for the Quilchena macroflora (Table 3). Based on the analyses here, the combination of MAT in the lower end of the mesothermal range, and CMMT c. 5$8^{\circ} \mathrm{C}$ and MAP c. $100 \mathrm{~cm} / \mathrm{yr}$ is not found in middle latitudes North America (i.e. 30$50^{\circ} \mathrm{N}$ ), nor even in west coast sites (e.g. Portland, Oregon), or at low latitudes (i.e. 10$20^{\circ} \mathrm{N}$; e.g. Mexico City). The low latitude, high elevation sites show higher CMMT for comparable MAT than middle latitude moderate elevation sites in the southern hemisphere (e.g. Armidale, Australia). The combination of moderate seasonal temperature range and lower mesothermal range MAT reconstructed for Quilchena in the Early Eocene is therefore best represented today not in high elevation tropical sites, but in middle latitude sites in the southern hemisphere.

\section{Palynological analysis}

Figure 8 summarizes the main pollen taxa recorded for five Quilchena sediment samples, and figures 9 and 10 present images of selected gymnosperms and angiosperms respectively. Preservation is generally poor to moderate, with compression, punctures, and exine degradation making identifications difficult, but well-preserved and diagnostic pollen types are present, such as Ginkgo type (Fig. 9A). A comparison with the pioneering, but unpublished study of Hills (1965), confirms his conclusion that bisaccate conifer pollen dominates in coarser clastics, and the 
cupressaceous/taxodiaceous types (Fig. 9B) dominate in finer shales. This pattern is apparent in Fig. 8 where total bisaccates (sum of Pinus (Fig. 9C), Pseudolarix 9D, Picea (9E), and Abies (9F) reach $\sim 60 \%$ in facies 2 mudstones, and only $20-30 \%$ in the fine shales of facies 1. Rare gymnosperms that require more study for confirmation are cf. Sciadopitys (Fig. 9G) and hemlock type (Tsuga Fig. 9H)).

The high values of the Cupressaceae type pollen in some samples support the presence of local swamps, since this general pollen morphology, also referred to as TCT (Taxodiaceae-Cupressaceae-Taxaceae) in Fig. 8 and various publications, is typical of swamp cypress trees (Taxodium and Glyptostrobus), Chamaecyparis, Thuja, and Metasequoia, all confirmed by macrofossils, and ecologically indicative of moist to swampy soils. Metasequoia and Sequoia pollen are identifiable by a papilla in ideal conditions, but papillate pollen were only infrequently seen at Quilchena, although macrofossils of Metasequoia are abundant. The presence of coal at Quilchena along with the plant micro and megafossil indicators, confirms this interpretation of both lake and swamp environments at Quilchena. Thin coaly stringers are occasionally exposed at the Quilchena Creek fossil site (Fig. 2), suggesting that swampy conditions existed around the margins of paleolake Quilchena, as suggested in Figure 12.

Angiosperms are present in all samples and prominent (>5\%) in some, notably alder (Alnus, Fig. 10A), triporate grains of various Betulaceae (10B-D), Ulmus (10E), and Pterocarya $(10 \mathrm{H})$. The absence of the indicator pollen Pistillipollenites mcgregorii (Fig. 10I) from all samples except the unprecedented high values of $90 \%$ from the coal mine ironstone is puzzling, since Hills (1965) considered Quilchena to fall within a stratigraphic zone defined by the presence of this taxon! This value is so outside the normal abundance range (1-5\%) that it probably indicates the inclusion of 
flowering material in the sample of ironstone, but does confirm the presence of this Early to Middle Eocene indicator species (Rouse 1977). Hills (1965) sampled only at the coal mine locality on the East side of Quilchena Creek (Cockfield 1948, map 886A), and finding Pistillipollenites only at that site suggests that two different pollen zones may be present at Quilchena, as claimed by Hills (1965). Other mostly rare angiosperm pollen include cf. Platanus (Fig. 10F), hickory (Carya, Fig. 10G), basswood (Tilia, Fig. 10J), sweet gum (Liquidambar, Fig. 10K), and others.

Of special note is the rare occurrence of monocolpate pollen similar to the palm genus Sabal, but named as Liliacidites (Fig. 10L) in this paper and in Archibald et al. (2014) because it is larger than Sabal granopollenites, a form genus defined by Rouse (1962) and found by others (Hopkins, 1969) in the coastal Eocene of Vancouver where macrofossils of palms are also present. In the southern interior of British Columbia, rare Sabal pollen was recorded by Hills (1965), commonly at some OH sites by Moss et al. (2005) and as cf. Sabal granopollenites by Dillhoff et al. (2013). These pollen records suggest the presence of palms in the Okanagan Highlands vegetation, although macrofossils (Uhlia allenbyensis) are only known from the Princeton chert (Erwin and Stockey, 1994). The discovery of exclusively palm-feeding beetles at Quilchena (see next section) and elsewhere in the $\mathrm{OH}$ (Archibald et al. 2014) confirms that this pollen can be a proxy indicator of palm presence.

These preliminary results allow a basic comparison to other studies of Okanagan Highlands Eocene localities. Rouse et al. (1970, p. 232) noted that compared to the coastal Eocene, the interior exhibits "greater amounts of pinaceous and taxodiaceous pollen", and greater numbers of angiosperms extant to southeastern North America and east-central China, including Carya, Pterocarya, Juglans various 
Betulaceae, and Tilia, and fewer fern spores. This is generally apparent for Quilchena and other $\mathrm{OH}$ sites. The most recent published pollen records for the $\mathrm{OH}$ in Dillhoff et al. (2005), Moss et al. (2005), and Dillhoff et al. (2013) indicate a high degree of quantitative variability in pollen spectra, even within samples from the same site. In particular, some published pollen records of Pinus may actually represent Pseudolarix, . Moss et al. (2005) first highlighted this identification issue for the $\mathrm{OH}$, suggesting that Pseudolarix may be locally more abundant than pine, especially at Driftwood Canyon, Falkland, Hat Creek, Thomas Ranch and Republic. Further study is needed to resolve their relative abundances in the past, since pine macrofossils are typically more common than those of Pseudolarix. Dillhoff et al. (2005) did not separate Pseudolarix pollen from other bisaccates at McAbee, but combined the two taxa as Pinus/Pseudolarix at Thomas Ranch in the Princeton area (Dillhoff et al. 2013). At Quilchena (Fig. 8) the two genera were also not quantitatively separated, due to preservation and identification problems for most bisaccate grains, although Pseudolarix presence was confirmed (Fig. 9D) along with pine (Fig. 9C) and other bisaccates, using criteria in Zanni and Ravassi (2007).

Most $\mathrm{OH}$ localities also exhibit relatively low values of TCT pollen $(<15 \%)$, with the exception of Hat Creek, where Moss et al. (2005) reconstruct the bestdeveloped local "Palm-Swamp Cypress Association” from coal samples. The highest recorded TCT counts $(47-80 \%)$ are those from the Princeton basin, at the Thomas Ranch locality along the aptly named Coalmont Road. It appears that high TCT pollen values are indicative of swampy environments that were present at Quilchena, and may lead to the formation of coal deposits.

Paleoentomology 
and Mathewes, 2000). Many are wide-ranging across a variety of climate types, for example, trigonalid and vespid wasps (Archibald et al., this volume), but the nearest living relatives of some taxa (Fig. 11) have more specific climatic preferences that range from hotter low latitudes to more temperate mid-latitudes (Archibald and Mathewes, 2000).

Temperate-associated fossil taxa include sawflies of the family Tenthredinidae (Hymenoptera, Symphyta), aphids (Hemiptera, Sternorrhyncha), giant lacewings (Neuroptera, Polystoechotidae), brown lacewings (Neuroptera, Hemerobiidae), and some scorpionflies (Mecoptera, Panorpoidea, Eorpidae). Aphids are well documented as showing a strong preference for temperate latitudes of the northern hemisphere (Dixon et al. 1987, Heie, 1994, Dixon 2012). Although a few species are found in the subtropics and tropics, they appear to be replaced there by other small plant fluid feeding sternorrhynchs (whiteflies, Aleyrodidae, and scale insects, Coccoidea) and a few are native to or introduced in the Southern Hemisphere. With over 6,000 species today, tenthredinid sawflies are the largest group of phytophagous Hymenoptera; yet they are also primarily a northern hemisphere mid-to-higher-latitude group, another notable exception to the latitudinal gradient of species diversity (Goulet 1993). Similarly, giant lacewings mostly inhabit temperate North America, but their range extends into Mexico and Central America in higher elevations, and they have a disjunct population in temperate, mid-latitude Chile (Archibald and Makarkin 2006). Extant congeners of the Quilchena brown lacewing Wesmaelius mathewesi are distributed across the Holarctic Region, and, as with the polystoechotids, the few species that range into lower latitudes are almost found always at high, cooler elevations (Makarkin et al. 
2003). The extinct scorpionfly family Eorpidae is only known from the Okanagan Highlands, but living Panorpoids also primarily range in northern hemisphere temperate mid-latitudes, with a few low latitude taxa that, like the lacewings, are almost always found in cooler, higher elevations (Archibald et al. 2013).

Quilchena insects characteristic of lower latitudes today include tropical cockroaches of the subfamily Diplopterinae (Blattodea, Blaberidae), dinidorid pentatomoid bugs (Hemiptera, Heteroptera), March flies (Diptera, Bibionidae, Plecia) and obligate palm-feeding leaf beetles of the subtribe Pachymerina (Coleoptera, Chrysomelidae, Pachymerinae, Pachymerina). The Quilchena dinidorid is a member of the extant genus Megymenum, close to species that now inhabit Southeast Asia and parts of Australia (Durai 1987). A number of specimens of the distinctively beetle-like tropical Australasian diplopterine cockroaches (Grandcolas 1993) have been recovered at Quilchena. Palm weevils (Pachymerina) feed on palm seeds and are native to the New World Neotropics and subtropics where palms grow. Flies of the genus Plecia (Diptera, Bibionidae) are very common at Quilchena, as they are throughout the Okanagan Highlands, and many Eocene localities throughout the world. Most species of Plecia are tropical today, with some ranging into the subtropics, e.g., in the southeastern United States.

\section{CONCLUSIONS}

This study confirms that the Quilchena fossil site formed under a mesothermal and moist paleoclimate during the Early Eocene Climatic Optimum (51$53 \mathrm{Ma}$ ). Based on bioclimatic analyses of 45 nearest living relatives of the fossil flora, and physiognomic analyses (leaf margin analysis, leaf size analysis, and CLAMP) of dicot leaves, Quilchena represents the warmest and wettest of the Okanagan Highlands 
fossil sites with comparable data. Comparison of the Quilchena estimates from bioclimatic analysis $\left(130 \pm 27 \mathrm{~cm} \cdot \mathrm{a}^{-1}\right)$ with reconstructed climate parameters from bioclimatic analysis in Table 3 of Greenwood et al. (2005, updated in Dillhoff et al. 2013) indicates that mean annual precipitation at Quilchena was higher than for all other studied Okanagan Highlands sites (all annual precipitation in cm.; Republic $115 \pm 39$, Falkland $105 \pm 48$, McAbee $108 \pm 35$, Horsefly $105 \pm 47$, One Mile Creek $114 \pm 42$ and Driftwood Canyon $102 \pm 63)$, and also higher than the recent report $(116 \pm 45 \mathrm{~cm})$ for Thomas Ranch (Dillhoff et al. 2013). Based on leaf physiognomy, mean annual precipitation for Quilchena is at the high end of the range for the Okanagan Highlands sites (Leaf area analysis estimates in cm. $\mathrm{a}^{-1}$ from Smith et al. 2012 and Dillhoff et al. 2013; Thomas Ranch $77+33 /-23$, McAbee $99+43 /-30$, One Mile Creek 108 +47/-33, Falkland $121+52 /-37$, Republic $135+111 /-61)$, but overlaps with other Okanagan Highlands sites within the large error ranges However, our CLAMP estimate for growing season precipitation $(117 \pm 32 \mathrm{~cm})$ at Quilchena for 7.6 months is higher than the 12 month mean annual precipitation estimates for most of the other sites, confirming the wet regime.

Figure 12 is an artistic interpretation of the shoreline of paleolake Quilchena based on the fossil record, showing some of the dominant vegetation and the presence of birds and a distinctive giant lacewing insect.

In addition to plant macrofossil data, fossil insects from Quilchena also support a highly equable climate with low temperature seasonality, even in this upland setting. This climate equability conclusion concurs with similar results from other Okanagan Hihglands sites (Greenwood et al. 2005). The absence or rarity of winter frost is supported by the evidence that palms were present during the EECO, based on palm- 
like pollen and especially on the presence at Quilchena and two other localities of obligate palm-feeding beetle fossils (Archibald et al. 2014). CLAMP results indicate a cold month mean temperature of $4.1^{\circ} \mathrm{C} \pm 3.4^{\circ} \mathrm{C}$, also supporting frost-free winter conditions that may have been constrained to perhaps as high as $8{ }^{\circ} \mathrm{C}$ on palm evidence (Royer et al. 2002, Archibald et al. 2014).

The unique climatic profile of Quilchena compared to other Okanagan Highlands sites leads to the conclusion that there is unexplained climatic variability during the ca. 3 million year long EECO (51-53 Ma). It is not known why Quilchena was warmer and wetter than other Early Eocene Okanagan Highlands sites, but it might reflect the particular age of the fossils $(51.5 \pm 0.4 \mathrm{Ma})$ during a short period of unusually warm conditions, or a unique physiographic position such as lower paleoelevation. Further work is now needed to compare fossil data, radiometric ages and climate parameters from other Eocene sites to try and reconstruct the pattern of Early Eocene climate change and its biological consequences during this period of global warming.

\section{ACKNOWLEDGEMENTS}

Financial support from NSERC discovery grants to RWM (DG-3835) and DRG (DG311934), and a CRE grant (9652-15) to DRG from the National Geographic Society, are gratefully acknowledged. Permission to collect fossils on the Quilchena Ranch property over many years was kindly given by Guy Rose. Steven Manchester kindly assisted with some plant macrofossil identifications. Special thanks to Glen Guthrie, whose M.Sc. thesis (1995) provided valuable information for this study, and to 
588 Christopher West (University of Saskatchewan), who ran the CLAMP analysis. We

589 thank two anonymous reviewers who provided edits and suggestions that improved the 590 manuscript.

591 


\section{REFERENCES}

Archibald, S.B. and Mathewes, R.W. 2000. Early Eocene insects from Quilchena, British Columbia, and their paleoclimatic implications. Canadian Journal of Zoology 78: 1441-1462.

Archibald, S.B., and Makarkin, V.N. 2006. Tertiary Giant Lacewings (Neuroptera: Polystoechotidae): revision and description of new taxa from western North America and Denmark. Journal of Systematic Paleontology 4: 119-155, 307. (DOI: 10.1017/S1477201906001817)

Archibald, S.B., Bossert, W.H., Greenwood, D.R., and Farrell, B.D. 2010. Seasonality, the latitudinal gradient of diversity, and Eocene insects. Paleobiology, 36: 374398. (DOI: 10.1666/09021.1).

Archibald, S.B., Greenwood, D.R., Smith, R.Y., Mathewes, R.W. and Basinger, J.F. 2011. Great Canadian Lagerstätten of the Okanagan Highlands (British Columbia and Washington State. Geoscience Canada 38: 155-164.

Archibald, S.B., Mathewes, R.W., and Greenwood, D.R. 2013. The Eocene apex of panorpoid scorpionfly family diversity. Journal of Paleontology 87: 677-695.

(DOI: $10.1666 / 12-129)$

Archibald, S.B., Morse, G.E., Greenwood, D.R., and Mathewes, R.W. 2014. Fossil palm beetles refine upland winter temperatures in the Early Eocene Climatic Optimum. Proceedings of the National Academy of Sciences (USA) Early Edition: 1-6. (www.pnas.org/cgi/doi/10.1073/pnas.1323269111)

Archibald, S.B., Rasnitsyn, A.P., Brothers, D., and Mathewes, R.W. (this volume). Preliminary overview of the early Eocene Hymenoptera of the Okanagan Highlands, far-western North America. Canadian Journal of Earth Sciences (this volume).

Breedlovestrout, R.L., Evraets, B. J., and Parrish, J.T. 2013. New Paleogene climate analysis of western Washington using physiognomic characteristics of fossil leaves. Paleogeography, Palaeoclimatology, Palaeoecology 392: 22-40. 
Burnham, R.J., Pitman, N.C.A., Johnson, K.R. \& Wilf, P. 2001. Habitat-related error in estimating temperatures from leaf margins in a humid tropical forest. American Journal of Botany 88: 1096-1102.

Cevallos-Ferriz, S.R.S. and Stockey, R.A. 1988. Permineralized fruits and seeds from the Princeton chert (Middle Eocene) of British Columbia: Lythraceae. Canadian Journal of Botany 66: 303-312.

Dawson, J.W. 1890. On fossil plants from the Similkameen Valley and other places in the Southern Interior of British Columbia. Proceedings and Transactions of the Royal Society of Canada, 8: 75-91.

Dillhoff, , R.M., Leopold, E.B. and Manchester, S.R. 2005. The McAbee flora of British Columbia and its relation to the Early-Middle Eocene Okanagan Highlands 5flora of the Pacific Northwest. Canadian Journal of Earth Sciences 42: 151-166.

Dillhoff, R.M., Dillhoff, T.A., Greenwood, D.R., DeVore, M.L., and Pigg, K.B. 2013. The Eocene Thomas Ranch flora, Allenby Formation, Princeton, British Columbia, Canada. Botany 91: 514-529. dx.doi.org/10.1139/cjb-2012-0313.

Dixon, A.F.G., Kindlmann, P., Leps, J., and Holman, J. 1987. Why there are so few species of aphids, especially in the Tropics. The American Naturalist 129: 580592.

Dixon, A.F.G. 1998. Aphid ecology: an optimization approach. 2nd edition. London, Chapman \& Hall, 1998. 300 pages

Durai, P.S.S. 1987. A revision of the Dinidoridae of the world (Heteroptera, Pentatomoidea). Oriental Insects 21: 163-360.

Eldrett, J.S., Greenwood, D.R., Polling, M., Brinkhuis, H., and Sluijs, A. 2014. A seasonality trigger for carbon injection at the Paleocene-Eocene thermal maximum, Climate of the Past 10: $1-11$.

Ellis, B., Daly, D.C., Hickey, L.J., Johnson, K.R., Mitchell, J.D., Wilf, P., Wing, S.L. 2009. Manual of Leaf Architecture, vol. 190. Cornell University Press, Ithaca.

Erwin, D.M. and Stockey, R.A. 1994. Permineralized monocotyledons from the Middle Eocene Princeton chert (Allenby formation)of British Columbia, Canada: Arecaceae. Palaeontographica Abt. B 1-2: 19-40. 
Fang, J., Wang, Z., Tang, Z. (Eds.), 2011. Atlas of Woody Plants in China, Distribution and Climate: Vols. 1 \& 2. Higher Education Press/Springer-Verlag, Beijing/Berlin, pp.1-1972.

Goulet, H. 1993. Superfamilies Cephoidea, Megalodontoidea, Orussoidea, Siricoidea, Tenthredinoidea, and Xyeloidea. in Goulet, H., and Huber, J.T. eds., Hymenoptera of the World pp. 101-129.

Grandcolas, P. 1993. The origin of biological diversity in a tropical cockroach lineage A phylogenetic analysis of habitat choice and biome occupancy. Acta OecologicaInternational Journal of Ecology 14: 259-270

Greenwood, D.R., Archibald, S.B., Mathewes, R.W and Moss, P.T. 2005. Fossil biotas from the Okanagan Highlands, southern British Columbia and northeastern Washington State: climates and ecosystems across an Eocene landscape. Canadian Journal of Earth Sciences, 42: 167-185.

Greenwood DR. 2007. North American Eocene Leaves and Climates: From Wolfe and Dilcher to Burnham and Wilf. In: Jarzen, D., Retallack, G., Jarzen, S. \& Manchester, S. (Eds.) Advances in Mesozoic and Cenozoic Paleobotany: studies in celebration of David L. Dilcher and Jack A. Wolfe. Courier Forschungsinstitut Senckenberg, 258: 95-108.

Grimm, G. W. and Denk, T. 2012. Reliability and resolution of the coexistence approach - A revalidation using modern-day data. Rev. Palaeobot. Palynol. 172: $33-47$.

Guthrie, G.H. 1995. A high resolution paleoecological analysis of an Eocene fossil locality from Quilchena, British Columbia. M.Sc thesis, Simon Fraser University, Burnaby, Canada.

Heie, O.E. 1994. Why are there so few aphid species in the temperate areas of the southern hemisphere? European Journal Entomology 91: 127-133

Hills, L.V. 1965. Palynology and age of Early Tertiary basins, interior of British Columbia. PhD dissertation, University of Alberta, Calgary, Alberta.

Hopkins, W.S. Jr. 1969. Palynology of Eocene Kitsilano Formation, southwestern British Columbia. Canadian Journal of Botany 47: 1101-1131. 
Kershaw, A.P., and Nix, H.A. 1988. Quantitative palaeoclimatic estimates from pollen data using bioclimatic profiles of extant taxa. Journal of Biogeography 15: 589602.

Makarkin, V.N., Archibald, S.B., and Oswald, J.D. 2003. New Early Eocene Brown Lacewings (Neuroptera: Hemerobiidae) from Western North America, The Canadian Entomologist, 135: 637-653.

Manchester, S.R., Chen, Z-D, Lu, A-M, and Uemura, K. 2009. Eastern Asian endemic seed plant genera and their paleogeographic history throughout the Northern Hemisphere. Journal of Systematics and Evolution 47: 1-42.

Mathewes, R.W. and Brooke, R.C. 1971. Fossil Taxodiaceae and new angiosperm macrofossils from Quilchena, British Columbia. Syesis, 4: 209-216.

Mosbrugger, V. and Utescher, T. 1997. The coexistence approach - a method for quantitative reconstructions of Tertiary terrestrial palaeoclimate data using plant fossils. Paleogeography, Palaeoclimatology, Palaeoecology, 134: 61-86.

Moss, P.T., D.R. Greenwood and S. B. Archibald. (2005). Regional and local vegetation community dynamics of the Eocene Okanagan Highlands (British Columbia - Washington State) from palynology. Canadian Journal of Earth Sciences 42: 187-205.

Mustoe, G.E. and Gannaway, W.L. 1997. Paleogeography and paleontology of the Early Tertiary Chuckanut Formation, Northwest Washington. Washington Geology 25: 3-18.

Natural Resources Canada 2012. Climatic Rangemap (1971-2000 scenario) / climatic profile. Canadian Forest Service, Sault Ste. Marie. http://planthardiness.gc.ca/index.pl?lang=en $\& \mathrm{~m}=13 \& \mathrm{p}=1$ (last access: May, 2012).

Penhallow, D. 1908. Report on Tertiary plants of British Columbia. No. 1013. Geological Survey Branch, Canada. Department of Mines, Ottawa, Ontario. 
Peppe, D., Royer, D.L., Cariglino, B., Oliver, S.Y., Newman, S., Leight, E., Enikolopov, G., Fernandez-Burgos, M., Herrera, F., Adams, J.M., Correa, E., Currano, E.D., Er-ickson, J.M., Hinojosa, L.F., Hoganson, J.W., Iglesias, A., Jaramillo, C.A., Johnson, K.R., Jordan, G.J., Kraft, N.J.B., Lovelock, E.C., Lusk, C.H., Niinemets, Ü., Peñuelas, J., Rapson, G., Wing, S.L., and Wright, I.J. 2011. Sensitivity of leaf size and shape to climate: global patterns and paleoclimatic applications. New Phytologist 190: 724-739.

Read, P.B. 2000. Geology and industrial minerals in the Tertiary Basins, south-central British Columbia. British Columbia Ministry of Energy, Mines, and Petroleum Resources Geofile 2000-2. British Columbia Ministry of Energy, Mines and Petroleum Resources, Victoria.

Rouse, G.E. 1962. Plant microfossils from the Burrard Formation of western British Columbia. Micropaleontology 8: 187-218.

Royer, D.L., Osborne, C.P. and Beerling, D.J., 2002. High $\mathrm{CO}_{2}$ increases the freezing sensitivity of plants: Implications for paleoclimatic reconstructions from fossil floras. Geology 30: 963-966.

Smith, R.Y., Basinger, J.F., and Greenwood, D.R. 2012. Early Eocene plant diversity and dynamics in the Falkland flora, Okanagan Highlands, British Columbia, Canada, Palaeobiodiversity and Palaeoenvironments 92: 309-328. doi: 10.1007/s12549-011-0061-5.

Spicer, R. A. 2015. CLAMP Online (Climate Leaf Analysis Multivariate Program). Available from http://clamp.ibcas.ac.cn/ [accessed September 4, 2015].

Thompson, R.S., Anderson K.H., and Bartlein, P.J. 1999. Atlas of Relations Between Climatic Parameters and Distributions of Important Trees and Shrubs in North America U.S. Geological Survey Professional Paper 1650 A\&B.

Thompson, R. S., Anderson, K. H., Bartlein, P. J., and Smith, S.A. 2000. Atlas of relations between climatic parameters and distributions of important trees and shrubs in North America; additional conifers, hardwoods, and monocots. US Geological Survey Professional Paper 1650 C, http://pubs.er.usgs.gov/publication/pp1650C. 386 pp. 
Thompson, R. S., Anderson, K. H., Pelltier, R. T., Strickland, L.E., Bartlein, P. J., and Shafer, S. L. 2012. Quantitative estimation of climatic parameters from vegetation data in North America by the mutual climatic range technique, Quaternary Science Reviews 51: 18-39.

Villeneuve, M. and Mathewes, R. 2005. An Early Eocene age for the Quilchena fossil locality, southern British Columbia. GSC, Current Research 2005-A4, 9 pp.

West, C.K., Greenwood, D.R., and Basinger, J.F. 2015. Was the Arctic Eocene 'rainforest' monsoonal? Estimates of seasonal precipitation from early Eocene megafloras from Ellesmere Island, Nunavut. Earth and Planetary Science Letters, 427: $18-30$.

Wilf, P., Wing, S.L., Greenwood, D.R., and Greenwood, C.L. 1998. Using fossil leaves as paleoprecipitation indicators: An Eocene example. Geology 26: 203-206.

Wilson, M.V.H. 1977. Middle Eocene freshwater fishes from British Columbia. Royal Ontario Museum, Life Sciences Contributions 13: 1-61.

Wilson, M.V.H. 1987. Predation as a source of fish fossils in Eocene lake sediments. Palaios 2: 497-504.

Wolfe, J.A. and Wehr, W. 1987. Middle Eocene dicotyledonous plants from Republic, northeastern Washington. U.S. Geological Survey Bulletin 1597.

Wolfe, J.A. 1979. Temperature parameters of humid to mesic forests of eastern Asia and relation to forests of other regions of the Northern Hemisphere and Australasia. U.S. Geological Survey Professional Paper, volume 1106, 37 p.

Yang, J., Spicer, R. A., Spicer, T. E., and Li, C. S. 2011. 'CLAMP Online': a new webbased paleoclimate tool and its application to the terrestrial Paleogene and Neogene of North America. Paleobiodiversity and Paleoenvironments 91: 163 183.

Zachos, J. C., Dickens, G. R., \& Zeebe, R. E. 2008. An early Cenozoic perspective on greenhouse warming and carbon-cycle dynamics. Nature 451: 279-283. 
Zanni, M., and Ravazzi, C. 2007. Description and differentiation of Pseudolarix amabilis pollen: palaeoecological implications and new identification key to fresh bisaccate pollen. Revue of Palaeobotany and Palynology 145: 35-75. doi:10.1016/j. revpalbo.2006.08.004.

769 
Table 1. Plant taxa recognised in the Quilchena fossil macroflora used for bioclimatic analysis $(n=45)$. Organ types: $r$ - reproductive; $f$ - foliage

\begin{tabular}{|c|c|c|c|}
\hline Fossil taxon & Family & Organ type & NLR used \\
\hline Azolla & Salviniaceae & $\mathrm{f}, \mathrm{r}$ & Azolla caroliniana \\
\hline Calocedrus & Cupressaceae & $\mathrm{r}$ & C. decurrens \\
\hline Chamaecyparis & Cupressaceae & $f, r$ & Chamaecyparis \\
\hline Glyptostrobus & Cupressaceae (taxodioid) & $f, r$ & G. pensilis \\
\hline Metasequoia & Cupressaceae (taxodioid) & $\mathrm{f}, \mathrm{r}$ & Metasequoia \\
\hline Sequoia & Cupressaceae (taxodioid) & $f, r$ & S. sempervirens \\
\hline Taxodium & Cupressaceae (taxodioid) & $f, r$ & Taxodium \\
\hline Thuja & Cupressaceae & $\mathrm{r}$ & Thuja \\
\hline Abies & Pinaceae & $\mathrm{r}$ & Abies \\
\hline Keteleeria & Pinaceae & $\mathrm{r}$ & Keteleeria \\
\hline Picea & Pinaceae & $\mathrm{r}$ & Picea \\
\hline Pinus & Pinaceae & $\mathrm{f}$ & Pinus \\
\hline Pseudolarix & Pinaceae & $\mathrm{r}$ & P. amabilis \\
\hline Tsuga & Pinaceae & $\mathrm{r}$ & Tsuga \\
\hline cf. Amentotaxus & Taxaceae & $\mathrm{f}$ & Amentotaxus \\
\hline Ginkgo & Ginkgoaceae & $\mathrm{f}$ & Ginkgo biloba \\
\hline Rhus & Anacardiaceae & $\mathrm{f}$ & Rhus \\
\hline Alnus parvifolia & Betulaceae & $\mathrm{f}, \mathrm{r}$ & Alnus \\
\hline Betula leopoldae & Betulaceae & $f, r$ & Betula \\
\hline Bignoniaceae & Bignoniaceae & $\mathrm{f}$ & Catalpa \\
\hline cf. Sambucus & Caprifoliaceae/Adoxaceae & $\mathrm{f}$ & Sambucus \\
\hline Joffrea/Nyssidium & Cercidiphyllaceae & $f, r$ & Cercidiphyllym \\
\hline Cornus & Cornaceae & $\mathrm{f}$ & Cornus \\
\hline Nyssa & Cornaceae & $\mathrm{r}$ & Nyssa \\
\hline Pieris & Ericaceae & $f, r$ & Pieris \\
\hline Eucommia & Eucommiaceae & $f, r$ & E. ulmoides \\
\hline Castaneophyllum & Fagaceae & $\mathrm{f}$ & Castanea \\
\hline Fagus & Fagaceae & $\mathrm{r}$ & Fagus \\
\hline Corylopsis & Hammamelidaceae & $\mathrm{f}$ & Corylopsis \\
\hline cf. Disanthus & Hammamelidaceae & $\mathrm{f}$ & Disanthus \\
\hline cf. Exbucklandia & Hammamelidaceae & $\mathrm{f}, \mathrm{r}$ & Exbucklandia \\
\hline cf. Pterocarya & Juglandaceae & $\mathrm{f}$ & Pterocarya \\
\hline Sassafras & Lauraceae & $\mathrm{f}$ & S. albidum \\
\hline Menispermaceae & Menispermaceae & $\mathrm{f}$ & Cissampelos \\
\hline Comptonia columbiana & Myricaceae & $\mathrm{f}$ & C. peregrina \\
\hline Fraxinus & Oleaceae & $\mathrm{r}$ & Fraxinus \\
\hline Hovenia & Rhamnaceae & $\mathrm{f}$ & H. dulcis \\
\hline Acer & Sapindaceae & $\mathrm{fr}$ & Acer \\
\hline cf. Aesculus & Sapindaceae & $\mathrm{f}$ & Aesculus \\
\hline Dipteronia & Sapindaceae & $\mathrm{r}$ & Dipteronia \\
\hline cf. Gordonia & Theaceae/Pentaphyllacaceae & $\mathrm{f}$ & G. lasianthus \\
\hline Ternstroemia & Theaceae/Pentaphyllacaceae & $f, r$ & Ternstroemia \\
\hline Tilia & Tiliaceae & $\mathrm{f}$ & Tilia \\
\hline Trochodendron & Trochodendraceae & $\mathrm{f}, \mathrm{r}$ & T. aralioides \\
\hline Ulmus & Ulmaceae & $\mathrm{f}, \mathrm{r}$ & Ulmus \\
\hline
\end{tabular}


Table 2. Estimates of climate variables based on leaf physiognomy. Errors provided are based on the binomial sampling error (equation 3 or 5), or from the CLAMP analysis.

\begin{tabular}{|l|c|c|c|c|}
\hline Method & $M A T\left({ }^{\circ} \mathrm{C}\right)$ & $\operatorname{CMMT}\left({ }^{\circ} \mathrm{C}\right)$ & $M A P\left(\mathrm{~cm} \cdot \mathrm{a}^{-1}\right)$ & $G S P(\mathrm{~cm})$ \\
\hline Equation 1 & $16.2 \pm 2.0$ & -- & -- & -- \\
\hline Equation 2 & $14.6 \pm 4.8$ & -- & -- & -- \\
\hline Equation 4 & -- & -- & $121 \pm 39$ & -- \\
\hline CLAMP & $13.3 \pm 2.1$ & $4.1 \pm 3.4$ & -- & $117 \pm 32$ \\
\hline
\end{tabular}

Table 3 Climate of the Early Eocene Quilchena site based on bioclimatic analysis contrasted to examples of 'equable' modern localities.

\begin{tabular}{lccccc} 
Site & Latitude & $\begin{array}{c}\text { Elevation } \\
(\mathrm{m})\end{array}$ & $\begin{array}{c}\text { MAT } \\
\left({ }^{\circ} \mathrm{C}\right)\end{array}$ & $\begin{array}{c}\text { CMMT } \\
\left({ }^{\circ} \mathrm{C}\right)\end{array}$ & $\begin{array}{c}\text { MAP } \\
\left(\mathrm{cm}^{-1} \mathrm{a}^{-1}\right)\end{array}$ \\
\hline Quilchena, BC & $50^{\circ} 7.7^{\prime} \mathrm{N}$ & 700 & $14-16$ & $3.5-7.9$ & $130 \pm 27$ \\
Vancouver, BC & $49^{\circ} 17^{\prime} \mathrm{N}$ & 3 & 9.9 & 3.0 & 117 \\
Portland, OR & $45^{\circ} 36^{\prime} \mathrm{N}$ & 6 & 12.6 & 4.6 & 95 \\
Charleston, SC & $32^{\circ} 54^{\prime} \mathrm{N}$ & 10 & 18.3 & 10.0 & 131 \\
Armidale, Aust. & $30^{\circ} 19^{\prime} \mathrm{S}$ & 980 & 13.9 & 6.9 & 76 \\
Mexico City & $19^{\circ} 26^{\prime} \mathrm{N}$ & 2237 & 15.0 & 12.2 & 58 \\
Guatemala City & $14^{\circ} 37^{\prime} \mathrm{N}$ & 1480 & 18.9 & 17.2 & 132 \\
\hline
\end{tabular}




\section{Figure Captions}

Figure 1. Location map of Okanagan Highlands localities, Quilchena settlement starred. Inset shows location of the Quilchena main fossil locality on west side of Quilchena Creek Valley, about $3 \mathrm{~km}$ south of the settlement.

Figure 2. Stratigraphic column showing numbered sediment units from Guthrie (1995) for fine-grained facies 1 , and coarser blocky mudstones with sandy beds with bentonite and coaly layers in facies 2 . Guthrie (1995) interpreted facies 1 as offshore in origin, with facies 2 a more near-shore unit. The argon date of $51.5 \pm 0.4 \mathrm{Ma}$ comes from the base of the thick bentonite bed in facies 2, shown in Figure 3.

Figure 3. Exposed section of tilted facies 2 blocky mudstones excavated by G.H. Guthrie during the 1991-92 field season. The thick light-coloured bentonite unit 31 at right provided the sanidine sample for dating at its base.

Figure 4. Plate of selected fossil cryptogams and gymnosperms with some modern comparisons. A, whole plant of the floating aquatic fern Azolla, showing leafy branch cluster at top, and linear rhizoids in floating position. B, fossil cone of Calocedrus. C, modern Calocedrus decurrens cone. D, fossil winged seed at top compared to modern $C$. decurrens seed, both show the diagnostic extra dorsal wing and elongated seed body. E, Foliage shoot of Sequoia with single ovulate attached cone. F, fossil staminate inflorescence of Taxodium, G, partial foliage shoot of cf. Amentotaxus, showing stomatal bands on underside, $\mathrm{H}$, fossil cone scale of Pseudolarix, with two singed seeds still attached, I, two attached fossil cones of Glyptostrobus at left, with taxodioid foliage presumably also of Glyptostrobus. J, fossil winged seed of Keteleeria showing dorsal and ventral resin deposits (arrows). K, modern seed of Keteleeria amabilis showing comparable morphology of seed wing and resin deposits. (Scale bars $2 \mathrm{~cm}$, except $1 \mathrm{~cm}$ for $\mathrm{J} \& \mathrm{~K}$ )

Figure 5. Plate of selected angiosperm fossils with some modern comparisons. (Scale bars $1 \mathrm{~cm})$. A, Eucommia shoot with two attached leaf bases and two attached fruits at bottom. B, Detail of dispersed Eucommia fruit. C, Dispersed Dipteronia samara. D, theaceous fruit assigned to Ternstroemia, showing woody capsule and pedicel with stout inferior calyx and stigmatic remnants. Size and morphology compare well to modern Ternstroemia tepetazote. E, modern herbarium specimen (UBC) of Ternstroemia tepetazote from Mexico, showing woody capsule and entire-margined leaves. F, fossil theaceous leaf with entire margin and strong midrib and brochiodromous secondary venation, possibly of Ternstroemia. G, modern leaf of Gordonia lasianthus (Gainesville, Florida) with glandular teeth and brochiodromous secondary veins. H, fossil theaceous leaf of cf. Gordonia with comparable shape, venation, and tooth morphology. I, Comparison of leaf size and shape of modern (left) leaf of Pieris japonica, with similar fossil leaf at right. J-K, Fossil 
pendulous infructescence assigned to Pieris in J, with four capsules of ericaceous morphology, comparable to modern infructescences of Pieris japonica at K. L shows details of ericaceous 5-carpellate capsule with suture lines like those in $\mathrm{K}$. M, fossil leaf of Hovenia with diagnostic basal venation. N, two leaves of cf. Disanthus, a deciduous shrub endemic to China and Japan. O, connate leaf and attached petiole of Menispermaceae, similar to modern Cissampelos. Arrow indicates the strong fimbrial vein enclosing the leaf edge.

Figure 6. Selection of entire-margined fossil leaves used in bioclimatic analysis (scale bars $=2 \mathrm{~cm}$ ). A, leaf of extinct Plafkeria (Malvaceae). B, unlobed leaf of Sassafras (Lauraceae). C, trilobed leaf of Lauraceae type. D, E, F, unknown leaf morphotypes. G, large bignoniaceous leaf similar to Catalpa. H, cf. Magnoliaceae leaf. I, unknown leaf.

Figure 7. Bioclimatic plots for mean annual temperature (MAT) and cold month mean temperature (CMMT) of nearest living relatives for 45 identified plant fossils, and mean annual precipitation (MAP) based on leaf size analysis.

Figure 8. Pollen diagram of samples from facies 1 and 2 of main Quilchena Creek fossil site, and two samples from coal mine spoil on east side of Quilchena Creek Valley.

Figure 9. Selected gymnosperm pollen from mixed shales of Quilchena Creek fossil site under oil immersion, A, B, and H under Nomarski Differential Interference, and others under brightfield illumination. A, Ginkgo type monosulcate pollen. B, two split Cupressaceae (taxodioid) pollen types. $\mathrm{C}$, Pinus pollen, showing the distinct edge the cap and interbladder membrane in equatorial view. D, Pseudolarix pollen showing the indistinct boundary between cap and intersaccate membrane compared to pine. E, Picea grain showing bladders continuous with cap. F, Abies grain with thick cap wall at top. G, cf. Sciadopitys pollen, with verrucate surface. H, Tsuga pollen grain.

Figure 10.Selected angiosperm pollen from Quilchena mixed shales and ironstone (I only). (Scale bars $=30 \mu \mathrm{m}$ ). A, Alnus 5-porate grain. B, cf. Carpinus 4pored pollen. C, Betula type triporate pollen. D, Corylus type triporate pollen. E, Ulmus type 4-porate grain. F, cf. Platanus reticulate tricolpate pollen. G, Carya pollen grain, with three pores and circular tetrad scar. $\mathrm{H}$, Pterocarya grain. I, cluster of Pistillipollenites grains from coal mine ironstone, showing the distinctive gemmate ornamentation. J, Tilia type malvaceous pollen. K, periporate pollen of Liquidambar. L, monocolpate microreticulate pollen of Liliacidites, similar except for larger size to palm pollen type Sabal granopollenites Rouse.

Figure 11.Fossil insects from Quilchena, selected as paleoclimatic indicators: A-E, forewings of temperate associated insects. $\mathrm{F}-\mathrm{H}$, insects associated with warmer, lower latitudes. A, Polystoechotities sp. A, Q-0041, a polystoechotid giant lacewing. B, Q-0096, a panorpoid scorpionfly, 
Eorpa jurgeni. C, Q-0391, an aphid. D, Q-5147A, a sawfly of the family Tenthredinidae. E, Q-0092, the brown lacewing Wesmaelius mathewesi. $\mathrm{F}, \mathrm{Q}-0516 \mathrm{~A}$, the beetle-like hardened forewing of a diplopterine cockroach. G, Q-5006, a March fly (Plecia sp.). H, Q-0195A, a dinidorid bug (Megymenum sp.). I, Q-0061A, an obligate palm-feeding bruchid leaf beetle. Scalebars: A, $10 \mathrm{~mm}$, all others $2 \mathrm{~mm}$.

Figure 12. Watercolour reconstruction by RM of the Early Eocene paleolake shoreline at Quilchena showing trunks of riparian trees such as swamp cypresses (Taxodium and Glyptostrobus), leaves of Theaceae in lower right, Metasequoia and Alnus leaves and cones at lower left, and Fraxinus samaras at upper right. Floating mats of Azolla and waterlily leaves occupy the shallow swampy area at middle right. Shoots of Decodon grow from the base of the large tree at right, and a vine of Menispermaceae or Icacinaceae is climbing the trunk. Various small trees and shrubs dot the shoreline. Birds and insects (polystoechotid giant lacewing in foreground, see Fig. 11A) are also present, with evidence of volcanic activity in the distance.

KEY WORDS: Early Eocene, Quilchena, Paleoclimate, paleobotany, fossil insects 


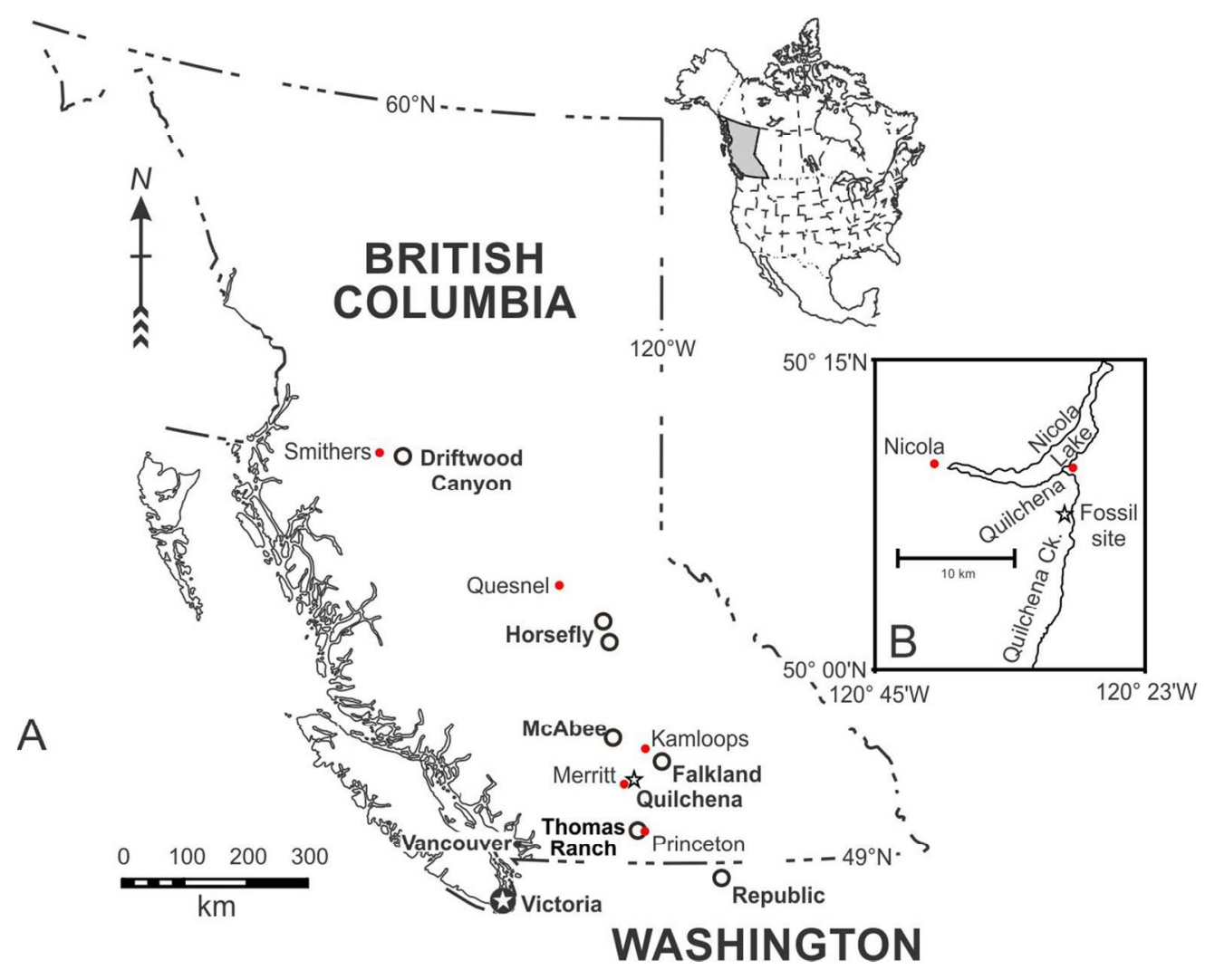

$113 \times 91 \mathrm{~mm}(300 \times 300$ DPI $)$ 


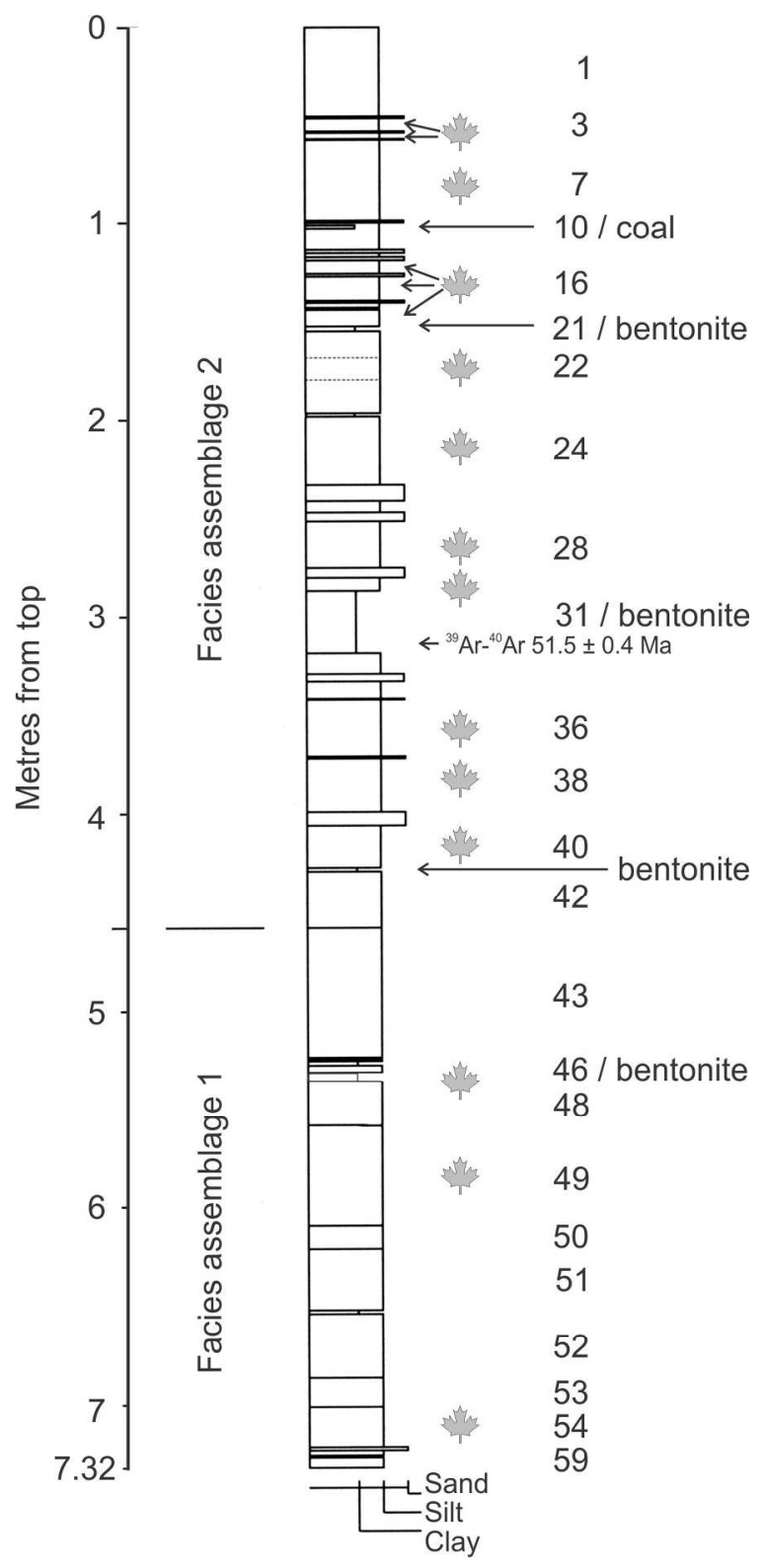

$112 \times 236 \mathrm{~mm}(300 \times 300 \mathrm{DPI})$ 


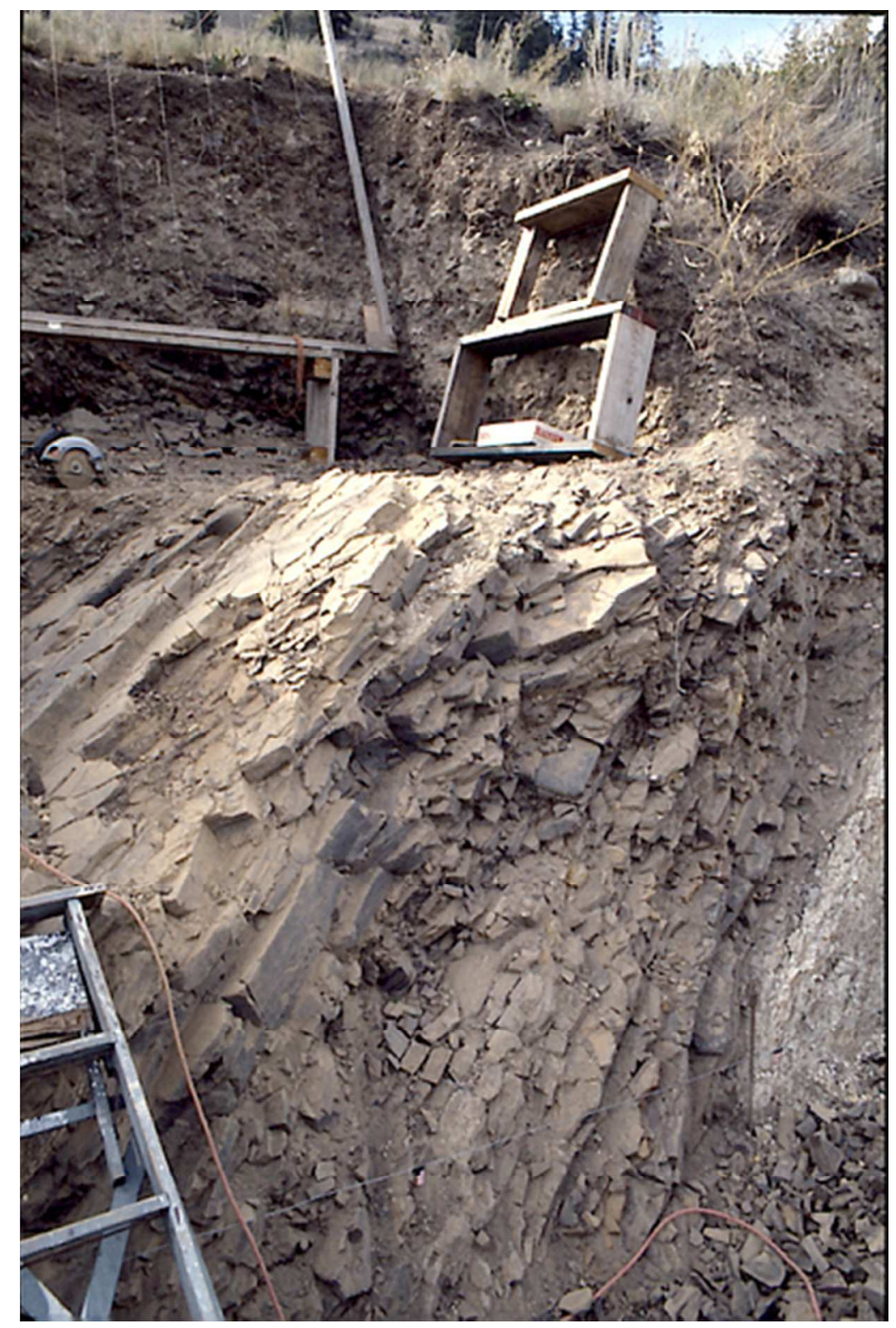

Figure 3.

$34 \times 51 \mathrm{~mm}(300 \times 300$ DPI) 

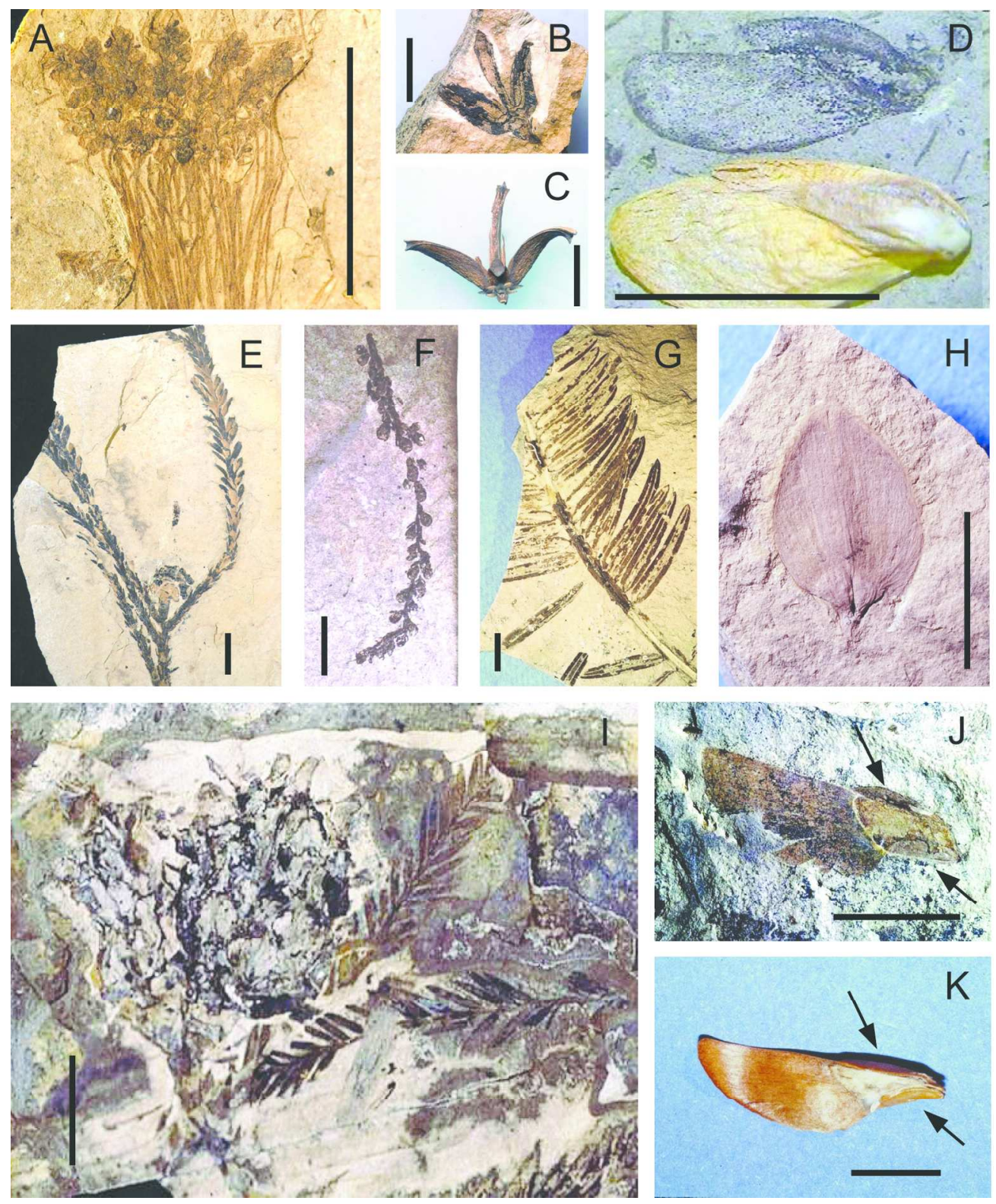

$163 \times 197 \mathrm{~mm}(300 \times 300 \mathrm{DPI})$ 

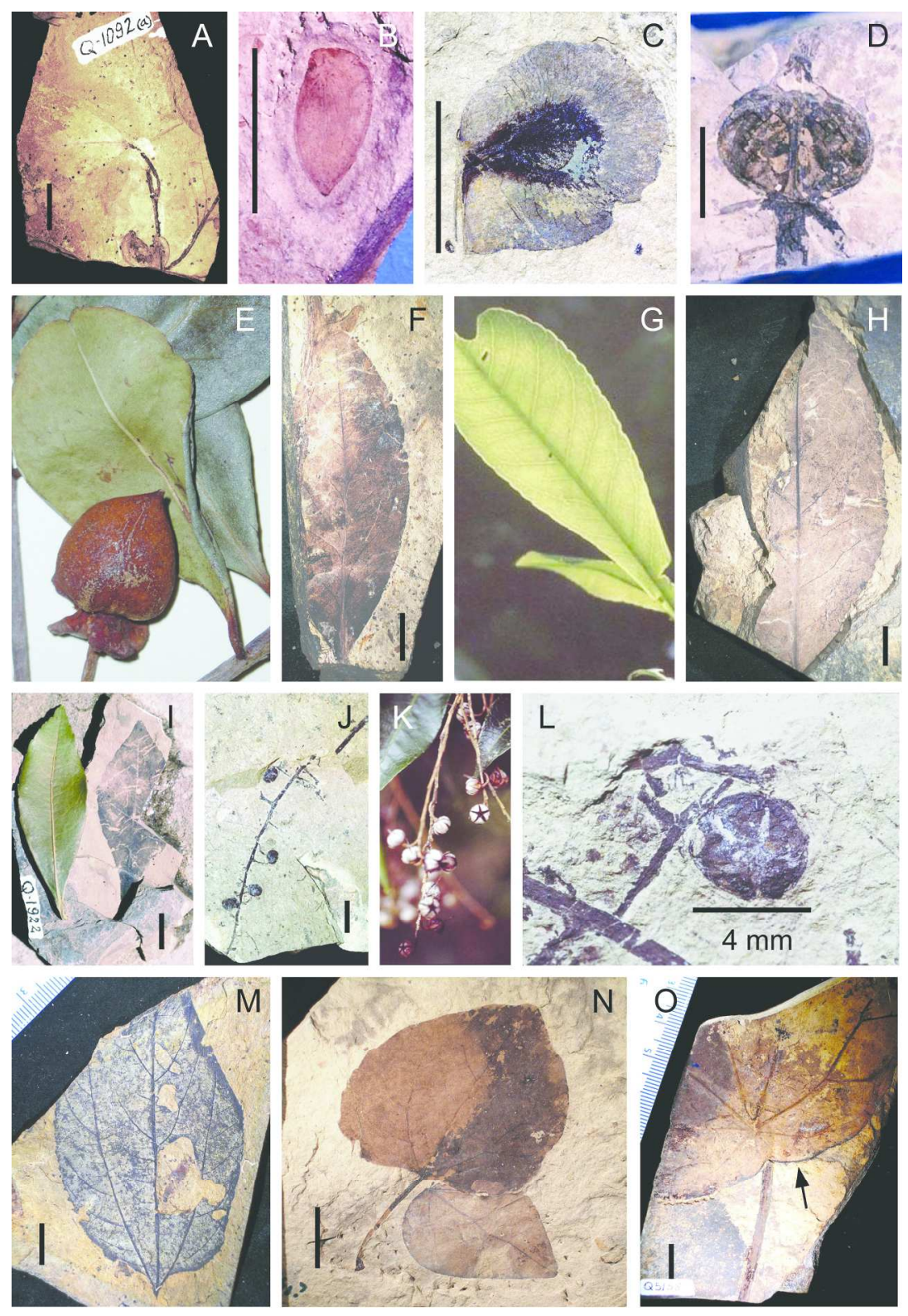

$176 \times 257 \mathrm{~mm}(300 \times 300$ DPI $)$ 

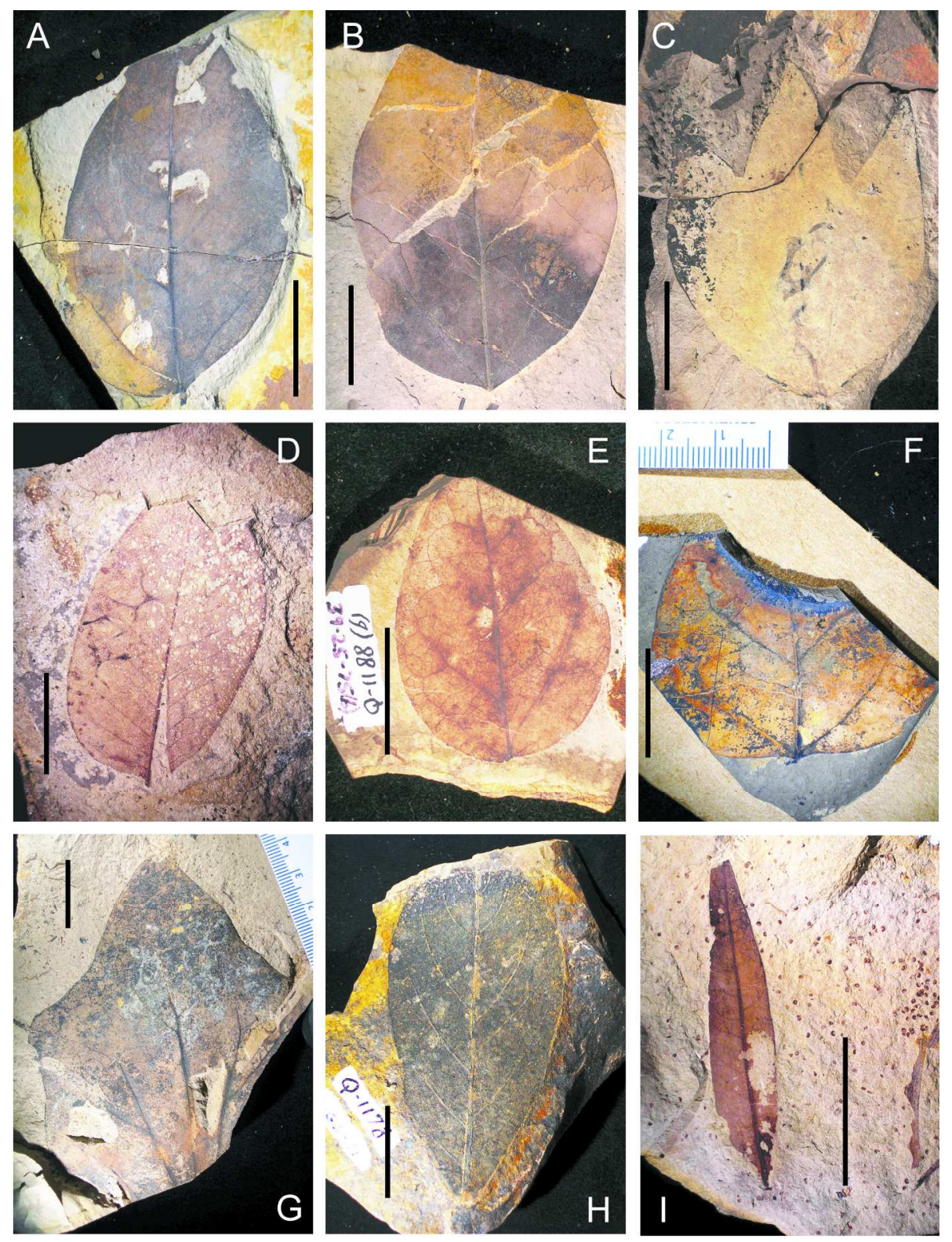

$185 \times 245 \mathrm{~mm}(300 \times 300 \mathrm{DPI})$ 
A

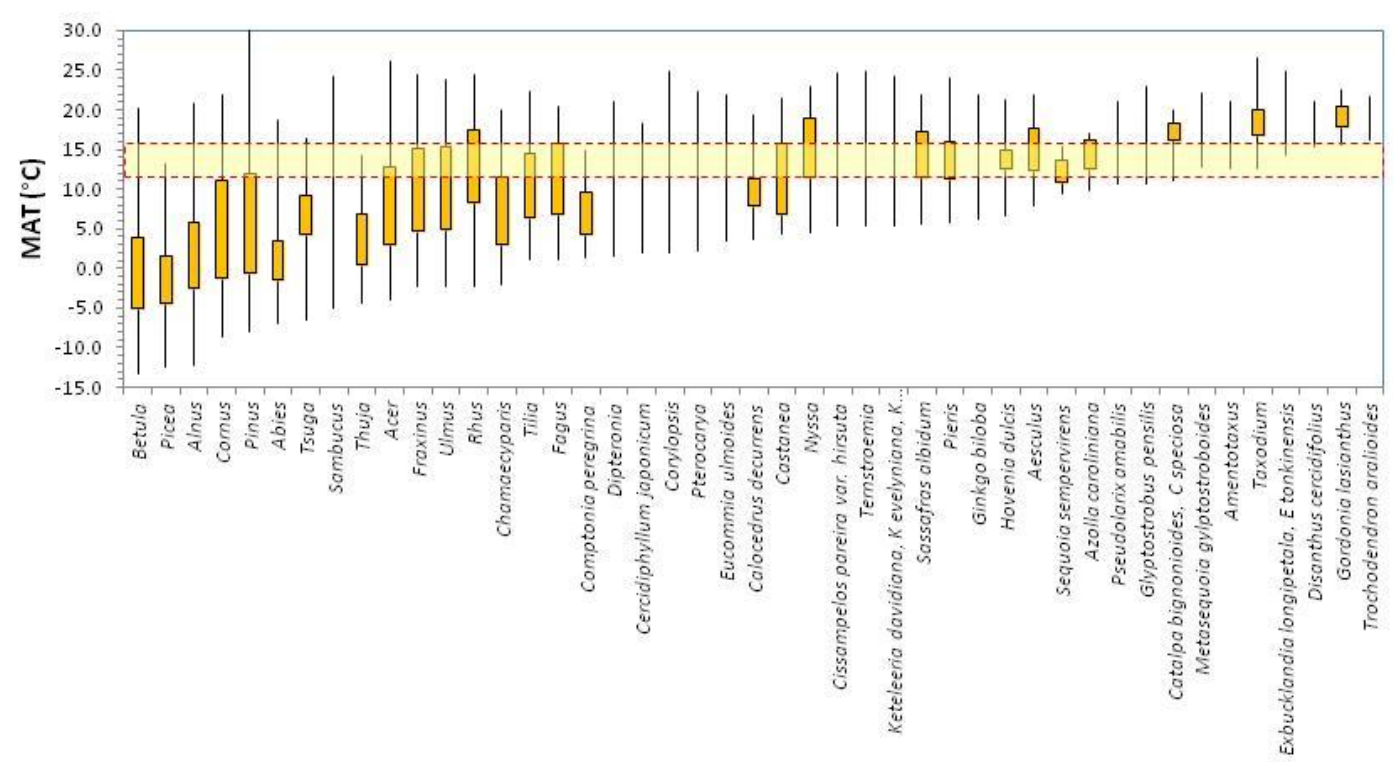

B

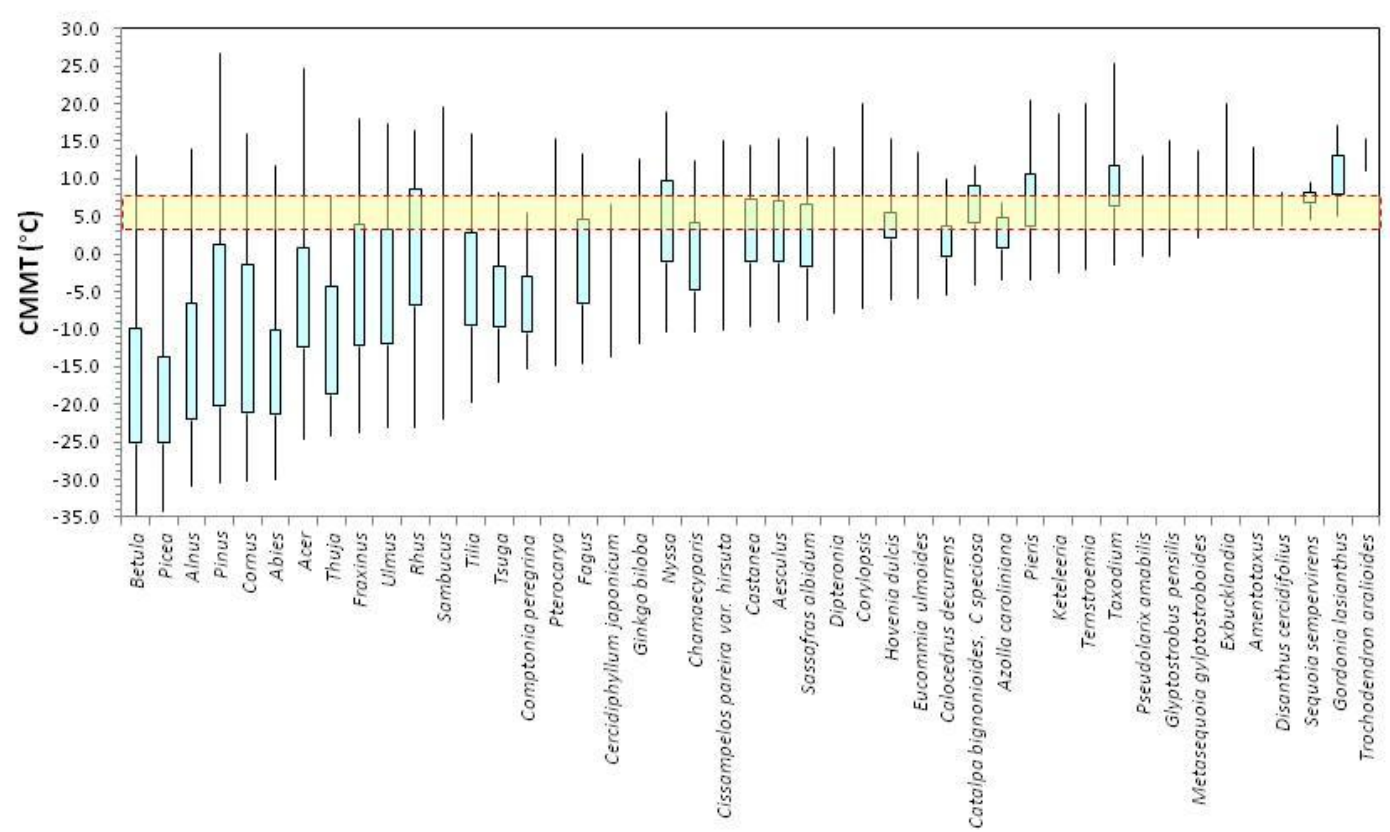

C

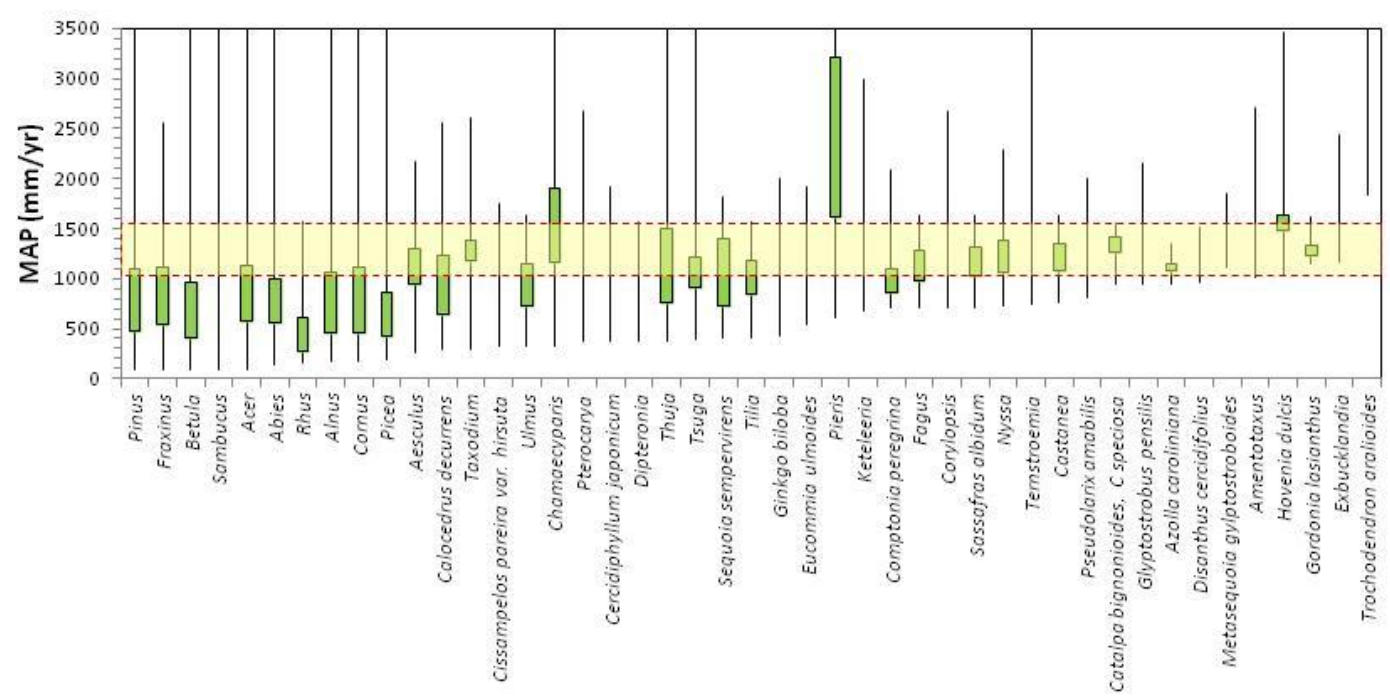




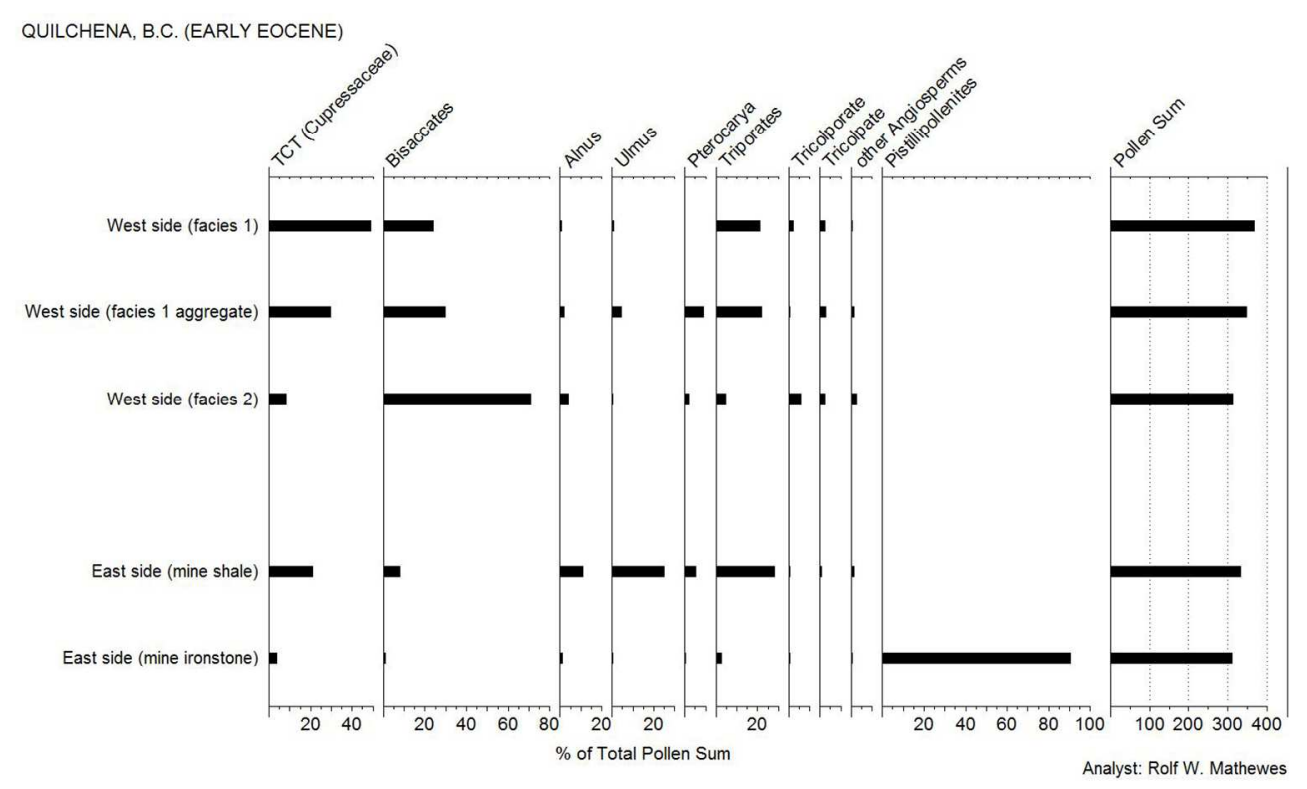

Figure 8.

$402 \times 247 \mathrm{~mm}$ ( $96 \times 96$ DPI) 

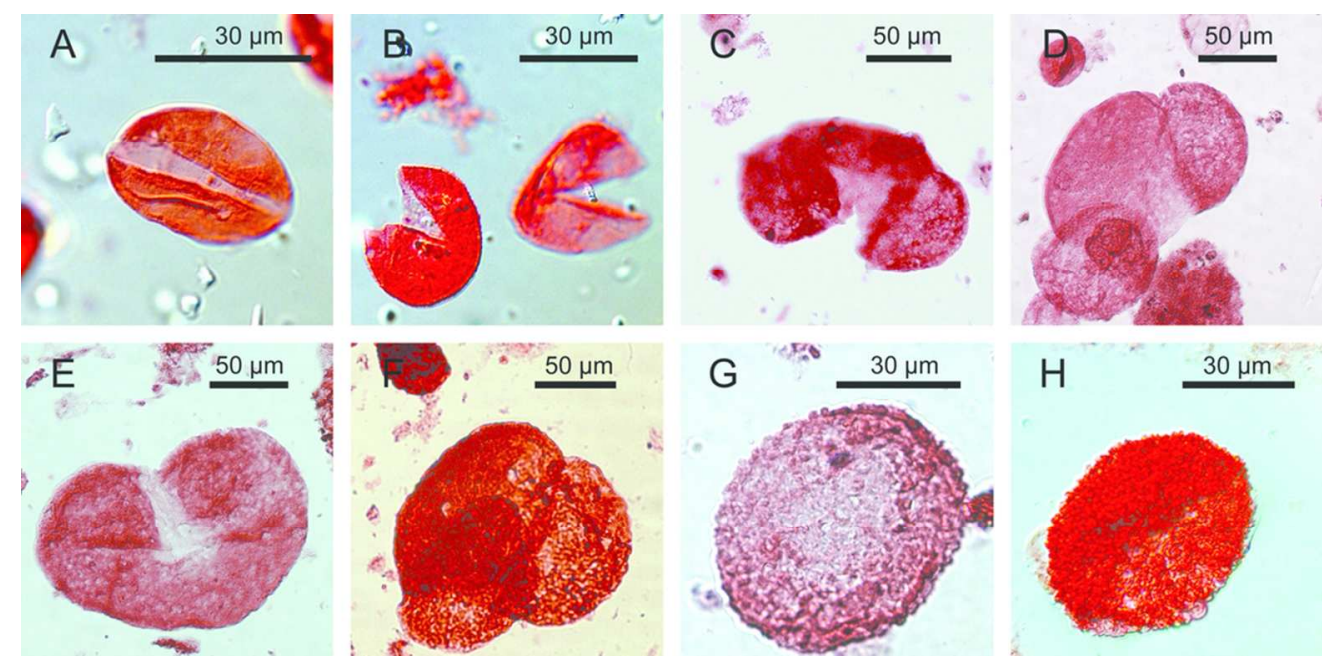

$92 \times 45 \mathrm{~mm}(300 \times 300$ DPI $)$ 

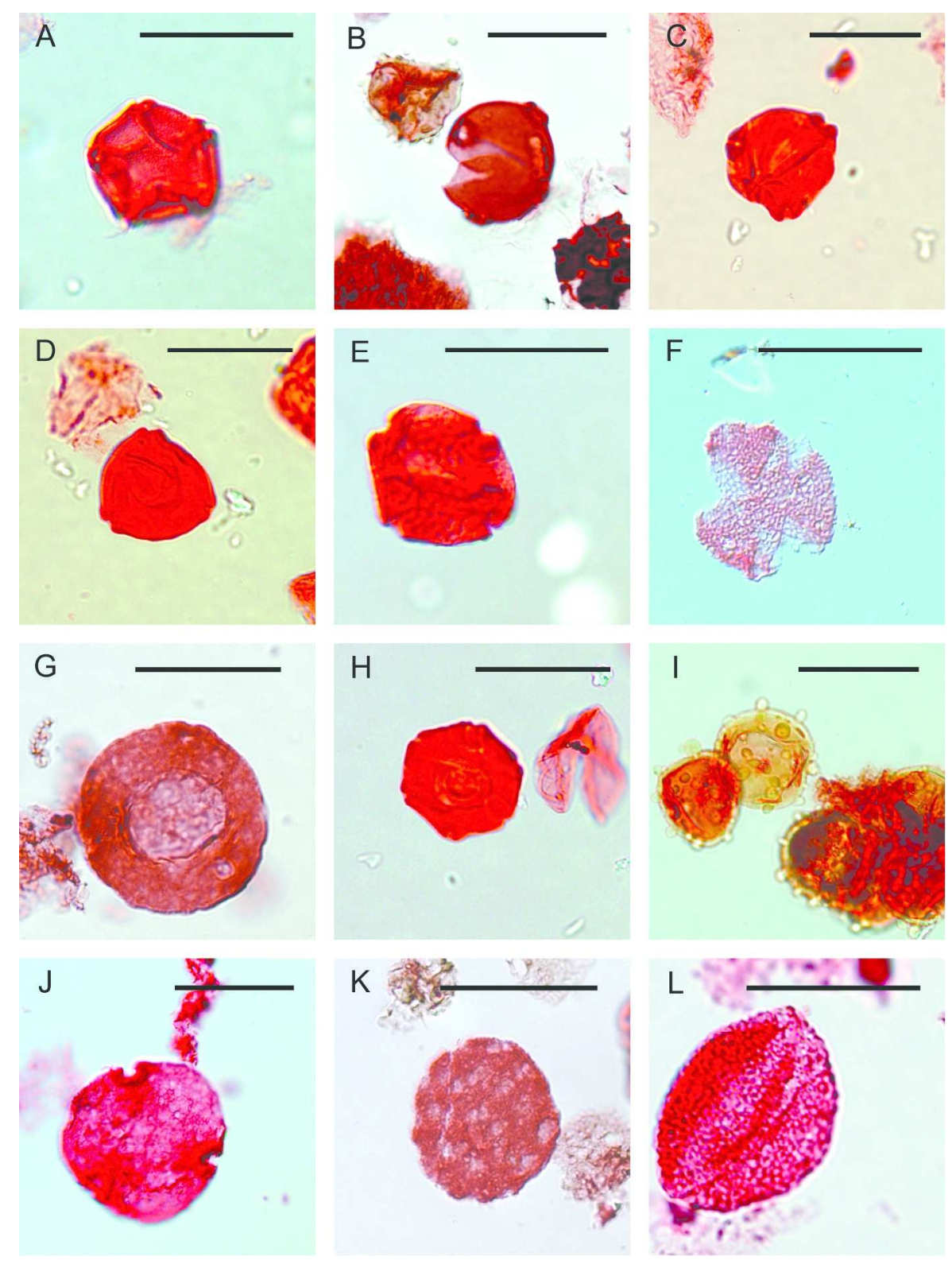

$191 \times 256 \mathrm{~mm}(300 \times 300$ DPI) 

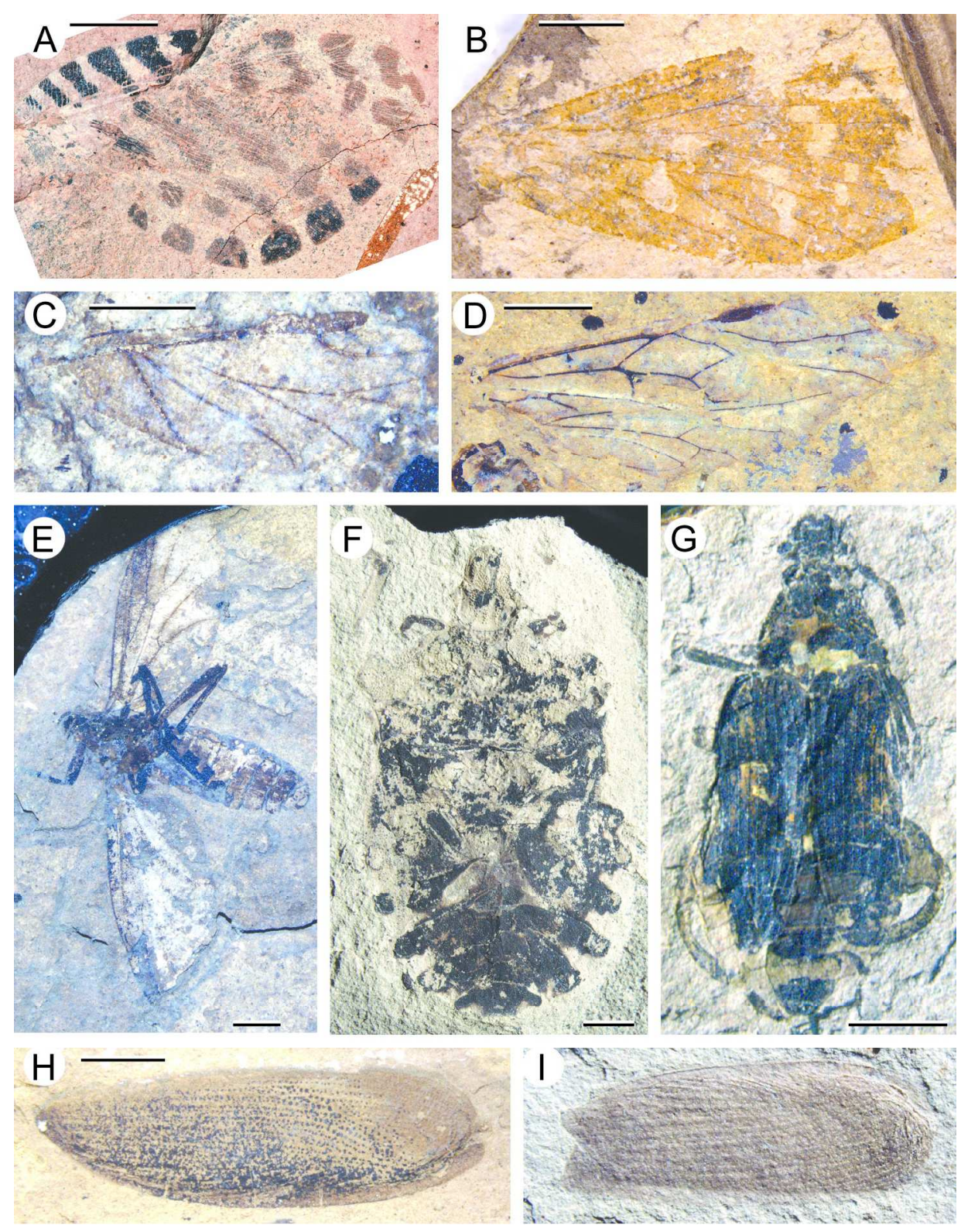

$185 \times 237 \mathrm{~mm}(300 \times 300 \mathrm{DPI})$ 


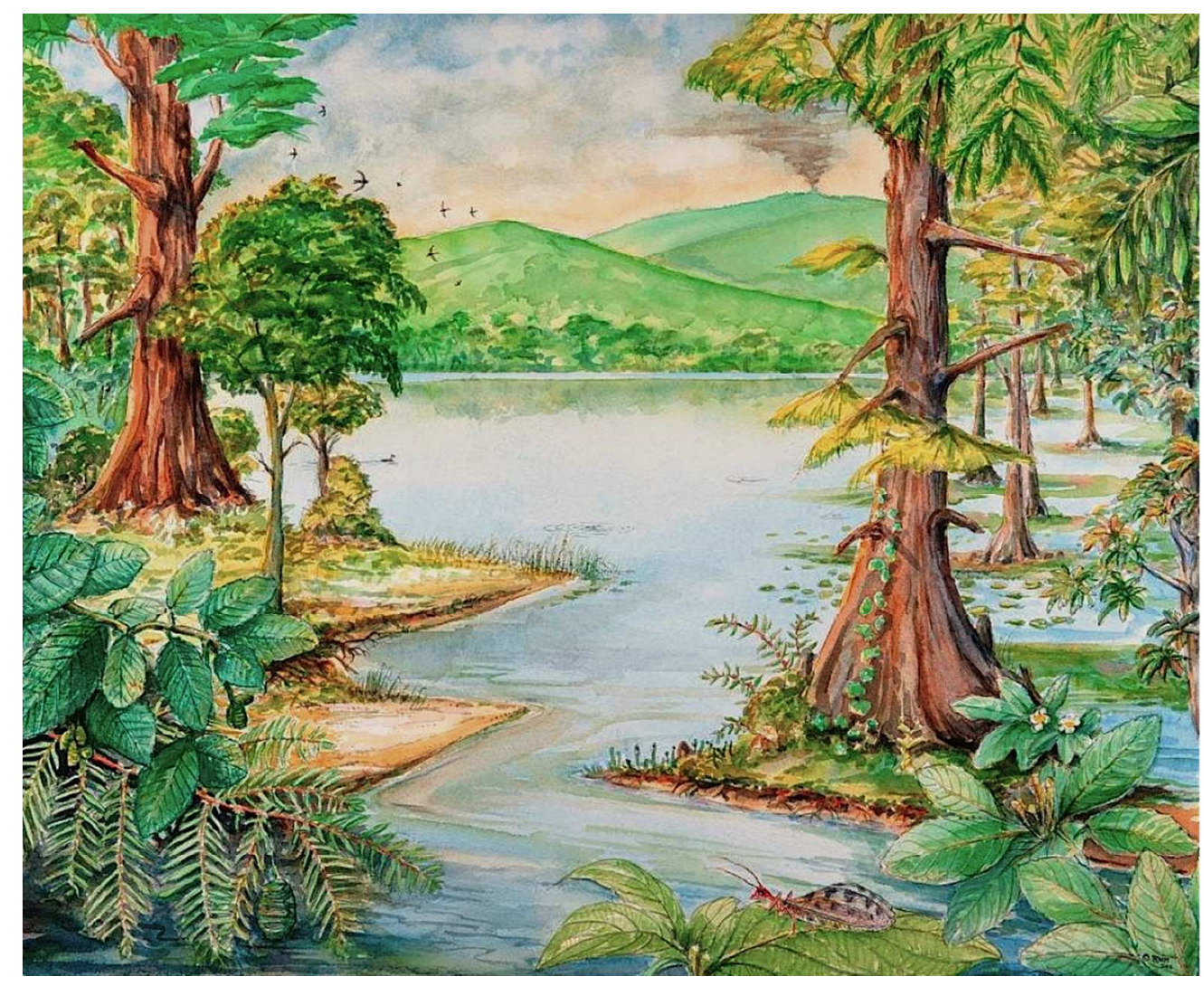

$181 \times 148 \mathrm{~mm}(150 \times 150 \mathrm{DPI})$ 